\title{
(83 IEB
}

Institut

d'Economia

de Barcelona

\section{Document de treball de l’IEB 2013/ 12}

THE MATHEMATICS SKILLS OF SCHOOL CHILDREN: HOW DOES ENGLAND COMPARE TO THE HIGH PERFORMING EAST ASIAN J URISDICTIONS?

J ohn J errim, Álvaro Choi 


\section{THE MATHEMATICS SKILLS OF SCHOOL CHILDREN: HOW DOES ENGLAND COMPARE TO THE HIGH PERFORMING EAST ASIAN JURISDICTIONS?}

John Jerrim, Álvaro Choi

The Barcelona Institute of Economics (IEB) is a research centre at the University of Barcelona which specializes in the field of applied economics. Through the IEBFoundation, several private institutions (Applus, Abertis, Ajuntament de Barcelona, Diputació de Barcelona, Gas Natural and La Caixa) support several research programs.

Postal Address:

Institut d'Economia de Barcelona

Facultat d'Economia i Empresa

Universitat de Barcelona

C/ Tinent Coronel Valenzuela, 1-11

(08034) Barcelona, Spain

Tel.: + 34934034646

Fax: + 34934039832

ieb@ub.edu

http://www.ieb.ub.edu

The IEB working papers represent ongoing research that is circulated to encourage discussion and has not undergone a peer review process. Any opinions expressed here are those of the author(s) and not those of IEB. 


\title{
THE MATHEMATICS SKILLS OF SCHOOL CHILDREN: HOW DOES ENGLAND COMPARE TO THE HIGH PERFORMING EAST ASIAN JURISDICTIONS?
}

\author{
John Jerrim, Álvaro Choi
}

\begin{abstract}
English policymakers have been disappointed with children's performance on TIMSS and PISA, particularly in comparison to the results of young people from East Asia. In this paper we provide new insight into the England - East Asia gap by considering how cross-national differences in math test scores change between ages 10 and 16. Our results suggest that, although average math test scores are higher in East Asian countries, this gap does not increase between ages 10 and 16. Thus, reforming the secondary school system may not be the most effective way for England to 'catch up'. Rather earlier intervention, during pre-school and primary school, may be needed instead.
\end{abstract}

JEL Codes: I20, I21, I28

Keywords: PISA, TIMSS, educational policy, primary education, secondary education.

John Jerrim

Department of Quantitative Social

Science, Institute of Education,

University of London

20 Bedford Way

London, WC1H 0AL (United Kingdom)

E-mail: J.Jerrim@ioe.ac.uk
Álvaro Choi

Universitat de Barcelona \& IEB

Facultat d'Economia i Empresa

Avda. Diagonal 690

08034 Barcelona (Spain)

E-mail: alvarochoi@ub.edu 


\section{Introduction}

One of the major developments in educational research over the last twenty years has been the widespread implementation of cross-national studies of pupil achievement, including the Programme for International Student Assessment (PISA), Trends in Mathematics and Science Study (TIMSS) and Progress in International Reading Literacy Study (PIRLS). These aim to produce cross-nationally comparable information on children's abilities at a particular age in at least one of three areas (reading, math and science). Regular reports are then published by the survey organisers where countries are ranked in terms of school children's test performance. This has had a major impact upon policymakers from a number of countries, with many treating these international 'league tables' as an evaluation of their school system's success. English policymakers have shown particular concern over England's position of $28^{\text {th }}$, out of 65 countries, in the PISA 2009 mathematics assessment. Although a few northern European countries have fared rather better (e.g. Finland), it is the consistently strong performance of East Asian nations that has really caught policymakers attention ${ }^{1}$. For instance, in the PISA 2009 mathematics study, Shanghai was ranked top, Singapore $2^{\text {rd }}$, Hong Kong $3^{\text {rd }}$, Korea $4^{\text {th }}$, Taiwan $5^{\text {th }}$ and Japan $9^{\text {th }}$. Given the important role of human capital in economic productivity and growth (OECD 2010; Hanushek and Wößmann 2008; Barro 2001) England has looked towards the strong performance of these countries with an envious glare. Indeed, it is now widely believed that if England does not raise the academic skill of its school children, then its long-run prosperity will suffer as a result.

This has led policymakers to consider what can be learnt from the East Asian nations to help English educational standards improve. For instance, the Secretary of State for Education Michael Gove recently stated that ${ }^{2}$ :

'These regions and nations - from Alberta to Singapore, Finland to Hong Kong, Harlem to South Korea - should be our inspiration' [Emphasis our own]

\footnotetext{
${ }^{1}$ Finland has only routinely taken part in the PISA study and not the other international assessments (e.g. PIRLS or TIMSS). On the other hand, a number of leading Asian economies (e.g. Hong Kong, Singapore) have participated in PISA, PIRLS and TIMSS for a number of years. It is the East Asian countries consistently strong performance (throughout various studies and numerous survey waves) that is perhaps most impressive.

${ }^{2} \mathrm{See}$ http://www.education.gov.uk/inthenews/inthenews/a0070008/secretary-of-state-comments-on-pisa-studyof-school-systems
} 
With agreement from the shadow Education minister Stephen Twigg ${ }^{3}$ :

'we must learn from high-performing nations like Japan'

Similarly, the East Asian nations have been highlighted as strong education systems in the on-going review of England's mathematics curricula (Department for Education 2011), with an implicit suggestion that at least some of their school practises and policies hold the key to England's future educational success. Table 1 illustrates this point still further, where educational and economic inputs are compared to educational outputs across England and four comparator countries (Japan, Hong Kong, Singapore and Taiwan). Despite similar levels of GDP per capita, public expenditure on education and school enrolment rates, educational outcomes towards the end of secondary school (as measured by PISA test scores) are significantly lower in England.

\section{$<<$ Table 1>>}

It is therefore surprising that we do not know more about the achievement gap between England and the high performing East Asian nations. Although insightful, studies such as PISA are often considered in isolation, providing a limited snapshot of children's abilities at one particular point in time. It would perhaps be more useful for academics and policymakers to understand the specific point(s) in the education system that England falls behind these world leaders, and whether this is being driven by the experiences of certain sub-groups. For instance, the math skills of English and East Asian children could be roughly equal at the end of primary school, but then markedly diverge during secondary school. In this situation, reform of secondary education would perhaps be the most obvious policy response. On the other hand, it could be that most of the England - East Asia achievement gap emerges early in children's life (e.g. differences are apparent even by age 10) and that cross-national differentials do not grow much further beyond this point. Indeed, as the evidence base currently stands, one cannot rule out the possibility that English children actually catch up with their East Asian peers during secondary school. In this situation resources and efforts for reform might be better concentrated at earlier points in children's life (e.g. before their $10^{\text {th }}$ birthday). It would also suggest that analysis of studies such as PISA, which focuses upon the latter stages of secondary school, would be of little use in

\footnotetext{
${ }^{3}$ See http://www.bbc.co.uk/news/education-18057883
} 
revealing why young people in East Asia are so much better at math than young people in England.

The aim of this paper is to thus develop a better understanding of how children's performance on internationally standardised math tests changes between ages 10 and 16, comparing the experiences of English children to those from the four aforementioned East Asian jurisdictions (Japan, Singapore, Taiwan and Hong Kong). This is, in our opinion, a vital first step towards identifying why children in East Asian countries outperform their English peers. Within this broad topic, we consider the following three specific issues.

Firstly, we illustrate how mean math test scores change with age. This is important for identifying the point(s) in the education system that English children fall behind young people in other countries (on average) and thus where efforts for school reform should be concentrated. Secondly, we investigate inequality in educational outcomes, and how the distribution of math skill changes between ages 10 and 16. Our initial focus will be upon the spread of achievement, and whether this widens or narrows in England relative to the four East Asian countries. This is followed by an assessment of whether the gap between the highest achieving children in England and highest achieving children in East Asia widens (or declines) during secondary school. This is a particularly prominent policy issue, as having a pool of very highly skilled individuals is vital for technological innovation and long-run economic growth (Bean and Brown 2005, Toner 2011). Finally, we consider an output-based measure of equality of educational opportunity, focusing upon math test score differentials between socio-economically advantaged and disadvantaged groups (a topic of much recent academic and political debate). Previous research has found that the socio-economic achievement gradient widens in England between the end of primary school and the end of secondary school (Goodman et al 2009, Ermisch and Del Bono 2012), but that the same is not true in other English-speaking countries (Ermisch et al 2012). However, there has been little work considering this issue using the TIMSS and PISA datasets, and how England compares with the high performing East Asian jurisdictions in this respect. We make this important contribution to the existing literature.

Our results suggest that, although average math test scores are higher in East Asian countries than England, differences do not seem to increase between the end of primary and the end of secondary school. However, the gap between the highest achieving school children in East Asia and the highest achieving school children in England does seem to widen 
between ages 10 and 16. We also find that the vast majority of the socio-economic achievement gradient in mathematics skills in England is already apparent by age 10. This leads to the following policy recommendations:

- To narrow the mathematics achievement gap with the leading East Asian nations, English policymakers should concentrate on educational reforms in primary and pre-school.

- Yet there is also a need to ensure that high achieving school children in England manage to keep pace with the highest achieving pupils in other countries during secondary school via, for instance, gifted and talented schemes.

- Further efforts are needed to raise the basic skills of disadvantaged groups, again with a focus on the primary and pre-school years.

- Over the longer-term, a cultural shift in England may be needed, where the importance of education is recognised and promoted by all.

The paper now proceeds as follows. In section 2 we describe our empirical methodology and the TIMSS and PISA datasets. Section 3 provides estimates of change in test scores between ages 10 and 16 for England and a series of comparator countries. This is followed in section 4 by a discussion of our findings and a series of policy recommendations.

\section{Data}

The aim of this paper is to examine the variation in children's math skills across countries, and how this changes between the end of primary school and the end of secondary school. Ideally, longitudinal data would be available, enabling one to track the progress of exactly the same children over time. Unfortunately cross-nationally comparative data of this type does not exist. The next best alternative is to use repeated cross-sectional data, where samples have been collected from the same, or very similar, cohorts of school children at various points in time. From such data one can draw inferences about the distribution of children's math skill at several ages, and thus how key points on the achievement distribution (e.g. mean, standard deviation, $10^{\text {th }}$ percentile, $90^{\text {th }}$ percentile) change between the end of primary school and the end of secondary school. The approach we take in this paper is to compare how these key statistics change across countries. 
To do so, we draw upon data from the following rounds of the PISA and TIMSS studies:

- $\quad$ The $4^{\text {th }}$ grade (age 9/10) TIMSS wave from 2003

- $\quad$ The $8^{\text {th }}$ grade (age 13/14) TIMSS wave from 2007

- The PISA (age 15/16) wave from 2009

Each of these resources collects nationally representative data and has been explicitly designed to facilitate comparisons of children's cognitive skills across countries (OECD 2011a and Olson et al 2008 provide further information). They also have similar sample designs, with schools firstly selected as the primary sampling unit and then either one or two classes (TIMSS) or 35 pupils (PISA) randomly chosen to participate (from within each school). In all the analysis that follows, we account for this clustering of children within schools by making the appropriate adjustment to the estimated standard errors (using either the STATA 'svy' survey command or by bootstrapping standard errors by cluster) ${ }^{4}$. Response rates for the countries included in our analysis can be found in Appendix 2. In most of the countries considered, school response was around 80 and 90\%, while pupil response typically stood at over $90 \%{ }^{5}$. In all three studies the survey organisers have produced a set of weights which attempt to correct for bias induced by non-response, while also scaling the sample up to the size of the national population. These weights are applied throughout the analysis ${ }^{6}$.

A notable feature of the three studies is that they collect data for children who were born at approximately the same time ${ }^{7}$. For instance, the two TIMSS studies for England refer to children who were born between September 1992 and August 1993, while those who took part in PISA 2009 were in the school year below (born between September 1993 and August 1994). Consequently, one can track the performance of a very similar cohort of children at three different ages $(9 / 10,13 / 14$ and 15/16). This is important if one wishes to interpret the changes observed as 'age' rather than 'cohort' effects. Although discussion shall focus on the performance of England relative to a set of leading East Asian nations, we include 13

\footnotetext{
${ }^{4}$ When considering mean test scores (section 3.1) and socio-economic gradients (section 3.3) we use the 'svy' STATA survey command. When investigating percentiles of the test distribution (section 3.2) estimates are bootstrapped by cluster (schools) using 50 replications to calculate approximate standard errors (see Appendix 1 for further details).

${ }^{5}$ The school response rate we refer to is after replacement schools have been included.

${ }^{6}$ Our experimentations with the data suggest substantive conclusions remain intact whether the weights are applied or not.

${ }^{7}$ The TIMSS studies collect information from children within the same school 'grade' (i.e. the same school year group), while in PISA children are all the same age (i.e. between 15 years 3 months and 16 years and 2 months old).
} 
countries that took part in each of these three studies into our analysis. This includes six from the rich western world (England, Scotland, Australia, Italy, USA, Norway), four Asian 'tiger' economies (Hong Kong, Japan, Singapore, Taiwan), and three with middle incomes (Lithuania, Russia, Slovenia). Some additional commentary shall be presented regarding England's performance relative to this broader set of countries.

It is important to recognize that there are some limitations with this empirical strategy. Firstly, although each study examines children's ability in mathematics, there are some conceptual differences in the skills being measured. For instance, whereas TIMSS focuses upon children's ability to meet internationally agreed curricula, PISA examines functional ability - how well young people can use the skills in 'real life' situations. Whether this slight difference in focus is of substantive importance is, however, questionable. For example, the correlation between children's PISA math test scores and a curricula based measure in England (key stage 3 scores) is high at over 0.80 (Micklewright and Schnepf 2006). Moreover, in Appendix 3 we also show the strong correlation $(r=0.88)$ between mean PISA and TIMSS $8^{\text {th }}$ grade test scores at the country level. We also note that other studies have used the PISA, PIRLS and TIMSS data to investigate the change in children's math skills as they age (e.g. Ammermueller 2005, Hanushek and Wößmann 2006, Waldinger 2007, Jakubowski 2010) ${ }^{8}$. Nevertheless, one cannot rule out the possibility that there are at least some subtle differences in the precise skills being measured.

Secondly, there are some differences between the surveys in the test score metric generated. In all three studies children's responses to the test questions are combined into a set of possible overall test scores via an item-response model ${ }^{9}$. Five 'plausible values' are then created for each child; these are five separate estimates of children's ability in mathematics. The intuition behind this process is that children's true ability cannot be observed, and must be estimated from their answers on the test. This results in a measure of children's achievement that has a mean of 500 and standard deviation of 100 in all three studies ${ }^{10}$. However each of the surveys contains a different pool of countries upon which these achievement scores are based. For instance, while PISA includes all members of the

\footnotetext{
${ }^{8}$ Indeed, the former head of the PISA study Andreas Schleicher has also anecdotally made such comparisons. See http://www.tes.co.uk/article.aspx? storycode $=6307101$

${ }^{9}$ A one parameter Rasch model PISA is used to generate test scores in PISA while a three-parameter item scaling procedure is used in TIMSS.

${ }_{10}$ In view of the large volume of data we are analysing, we use the first plausible value only throughout our analysis. OECD (2009: 129) note that 'analysing one plausible value instead of five plausible values provides unbiased population estimates'.
} 
OECD the two TIMSS studies do not. Consequently, although the test metric across the three surveys appears to be on the same scale, figures are not actually directly comparable (e.g. a mean score of 500 in PISA is not the same as a mean score of 500 in TIMSS).

To overcome this problem, all test score data are transformed (within each survey) into international z-scores. In other words scores have been normalised at the pupil level, so that in each survey the mean is 0 and the standard deviation is 1 across the 13 countries considered. This is a standard method for obtaining comparable units of measurement for variables that are on different scales and is similar to the approach taken by Brown et al (2007) in their comparison of the PISA and TIMSS datasets. One implication of this is that estimates refer to English pupils' test performance relative to that of children in the 13 other countries. Thus our focus is upon how England's performance relative to other countries changes between primary and secondary school. Terms like 'relative decline' shall therefore be used as international z-scores are comparative measures.

Similar difficulties arise when one considers the availability and comparability of children's background characteristics. For instance, the TIMSS studies contain very little information on pupils' socio-economic status. This poses a problem for estimating the socioeconomic gradient in mathematics achievement, and whether this gradient steepens as children age. We therefore turn to what many consider to be the best available proxy for family background that is contained within each of the three datasets and measured in a comparable way - the number of books in the family home ${ }^{11}$. Sociologists (e.g. Evans et al 2010) have argued that this reflects the scholarly culture of a household, and is thus a measure of the educational environment in which a child is being raised. On the other hand, various economists have argued that books in the home are 'the single most important predictor of student performance in most countries' (Wößmann 2008) and that there is evidence that this is a cross-nationally comparable proxy for socio-economic position (Hanushek and Wößmann 2010, Schütz et al 2008) $^{12}$. It has been widely used in this manner by various academics in analyses of the PISA, PIRLS and TIMSS datasets (Wößmann 2008,

\footnotetext{
${ }^{11}$ In a background questionnaire, children in PISA and TIMSS are asked about the number of books there are in their household, and instructed to tick the corresponding category.

${ }^{12}$ For instance, Hanushek and Wößmannn (2010) state 'Schütz, Ursprung, and Wößmannn (2008) corroborate the cross-country validity of the books-at-home variable by showing that the association between household income and books at home does not vary significantly between the six countries for which both income and books measures are available in the PIRLS dataset'.
} 
Waldinger 2007, Schütz et al. 2008, Ammermueller and Pischke 2009, Machin 2009, Evans et al 2010, Jakubowski 2010, Ermish and Del Bono 2010, Hermann and Horn 2011, Brunello et al 2012) including investigations of how the socio-economic gradient changes with age across countries (Jerrim and Micklewright 2012a, Ammermueller 2006). Nevertheless, Jerrim and Micklewright (2012a, 2012b) discuss some of the limitations with using books as an indicator of family background, focusing upon difficulties with measurement. We thus proceed with caution, acknowledging this to be an imperfect proxy for socio-economic status, though one which has been widely used in the data sources under our investigation.

In each dataset we use this variable in a series of OLS regression models to estimate how inequality of educational opportunity varies across countries. This takes the form:

$$
\mathrm{A}_{i j k}=\alpha+\beta_{1} \cdot \mathrm{SES}_{i}+\beta_{2} \cdot \operatorname{Sex}_{i}+\beta_{3} \cdot \mathrm{I}_{i}+\beta_{4} \cdot \mathrm{SES}_{i} * \mathrm{I}_{i}+\varepsilon_{i j} \quad \forall \mathrm{k}(1)
$$

Where:

A $=$ Children's score on the TIMSS or PISA math test

Sex $=$ A binary indicator of the child's gender $(0=$ female, $1=$ male $)$.

$\mathrm{I}=$ Whether the child is a first or second generation immigrant $(0=$ Native , $1=$ Immigrant $)$

$\mathrm{SES}=\mathrm{A}$ set of four dummy variables reflecting the number of books in the family home (Reference: Less than 25 books)

$\mathrm{i}=$ child $\mathrm{i}$

$\mathrm{j}=$ child $\mathrm{j}$

$\mathrm{k}=$ country $\mathrm{k}$

This specification follows the existing literature on international comparisons of socioeconomic achievement gradients (e.g. Schütz et al 2008, Wößmann 2008, Jerrim and Micklewright 2011, Jerrim 2012). Socio-economic status (as measured by books in the home) is the covariate of interest, with controls included for gender and whether the child was a first or second generation immigrant. As argued by Wößmann (2008) other characteristics (e.g. type of school attended) are intentionally not controlled, so that the SES parameter proxies all the channels by which family background influences children's test performance ${ }^{13}$. The

\footnotetext{
${ }^{13}$ We recognise that there are many important factors influencing children's educational development, including early education, parental education, material support, attitudes and aspirations. One would therefore ideally
} 
estimated coefficients will thus proxy the cumulative impact of family background on children's test performance, including their experiences during the first years of life (which Cunha et al 2006, amongst others, have stressed are extremely important). During this paper we focus upon test score differences between the most advantaged (more than 200 books) and least advantaged (less than 25 books) groups. Our primary interest is: (a) how does this socioeconomic achievement gradient vary across countries and (b) how does the gradient change as children move from the end of primary school to the end of secondary school.

Given the data difficulties described above, our analysis shall proceed with some caution. Specifically, our strategy is to treat the TIMSS $4^{\text {th }}$ grade survey as a broad indicator of children's math skills towards the end of primary school (when children are aged 9/10) with the TIMSS $8^{\text {th }}$ grade and PISA 2009 studies as two separate indicators of math skills towards the end of secondary school. Our intention is thus to look for evidence of robust changes in math achievement (at the country level) that hold whether either TIMSS 2007 ( $8^{\text {th }}$ grade) or PISA 2009 is used as the secondary school follow-up survey.

\section{Results}

\subsection{Average test scores}

In Table 2 countries are ranked by mean test scores at ages 9/10, 13/14 and 15/16. The countries of interest are highlighted in shades of light (England) or dark (East Asia) grey. At each point England sits in the middle of the cross-country ranking, with average test scores roughly in-line with those achieved by children from the United States. Indeed, on no occasion can one reject the null hypothesis that average test scores in England are significantly different from zero at the 5\% level. In other words, England's performance is always roughly in-line with the cross-national average (within this pool of 13 countries). A particularly notable feature of Table 2 is that the East Asian nations are consistently at the top of the international rankings, with a sizeable gap between this group and all other countries included in the analysis. For instance, even when children are in primary school (age 9/10) there is a big difference (almost 0.4 of an international standard deviation) between the lowest performing East Asian country (Taiwan) and the highest performing other country

include multiple variables into the analysis to capture these various effects. Unfortunately, the PISA and TIMSS dataset contain limited comparable information, and thus books in the home is used as the best available proxy to reflect the combined influence of such factors. A similar approach has been used by other authors when using these data (e.g. Wößmann 2008, Ammermueller 2006). 
included in the sample (Lithuania). Thus a substantial and statistically significant crossnational achievement gap has emerged long before the start of secondary school.

\section{$<<$ Table $2>>$}

England is clearly quite some distance behind the leading East Asian nations (in terms of pupils' average math achievement) before children reach their tenth birthday. But do English children fall further behind during secondary school? The answer to this question can be found in Table 3. This provides the change in average test scores between ages 10 and 14 (left hand columns) and 10 and 16 (right hand columns) across the 13 countries. The column labelled 'Sig Diff to 0' indicates whether there is a statistically significant change in a country's performance relative to the cross-national average between the two ages (based upon a two sample t-test with independence between surveys). On the other hand, the column labelled 'Sig Diff to Eng' illustrates whether there is a significant improvement or decline in average test scores relative to the change observed within England (based upon a two sample t-test assuming independence between countries within each of the surveys). This has similarities to a classic difference - in - difference test, where change in one 'treatment group' over time (e.g. English secondary schooling and culture) is compared to the change in other 'treatment groups' (e.g. various form of East Asian secondary schooling and culture).

\section{$<<$ Table $3>>$}

Starting with England, notice that the change in mean test scores between both ages 10 and $14(-0.107)$ and 10 and $16(-0.051)$ are small and statistically indistinguishable from 0 at conventional thresholds. Thus there is little evidence that the math skills of English children either improve or deteriorate (relative to young people in our pool of 13 countries) between the end of primary school and the end of secondary school (on average). This is in contrast to some countries (Norway and Slovenia) where average test scores clearly increase, while in others (Lithuania and Russia) there is a marked decline. Yet there is also little to suggest that English pupils fall further behind children in the leading East Asian nations. For instance, notice that the change in mean test scores between ages 10 and 16 in England is not significantly different to that in any of the East Asian countries. A similar result also seems to hold for Scotland (if anything, children in this country may actually catch up with their East Asian peers). This point is further emphasised in Figure 1, which plots mean test scores for the countries of interest at the three ages. Although the gap between England and the four East Asian countries is always large (often half an international standard deviation or more) 
there is no consistent evidence that the gap widens or declines during the primary (age 9/10) to secondary (age $13 / 14$ or $15 / 16$ ) transition.

\section{$<<$ Figure 1 $>>$}

A clear implication for policymakers is that it is not during secondary school that the leading East Asian countries pull away from England in terms of school pupils' math skills. Rather, the causal factor(s) behind these countries strong performance seemingly occurs much earlier in life (i.e. before the age of 9/10) and this relative advantage is then maintained. Consequently, reforming the secondary school system may not be the most effective way for England to 'catch up' with such countries in the PISA rankings. Earlier intervention (e.g. during pre-school and primary school) may be needed instead. Moreover, it seems unlikely that analysis of datasets that focus upon the latter stages of secondary school (like PISA) will be able to explain why average math performance is so much higher in East Asia than England.

\subsection{Inequality in educational outcomes}

Although England's relative performance in terms of pupils' average math test scores may not change significantly between primary and secondary school, it is possible that the distribution of achievement could alter as children age. Evidence on this matter can be found in Figure 2. This plots the standard deviation of children's math test scores at ages 9/10, 13/14 and 15/16 (note that Ferreira and Gignoux 2011 consider several possible measures of inequality in educational outcomes and conclude that the standard deviation is the most appropriate when analysing the international achievement datasets). England is highlighted using a light grey line with square markers.

\section{$<$ Figure $2>>$}

At age 9/10, inequality in mathematics achievement stands at roughly 1.1 international standard deviations in England. This is notably higher than in the East Asian nations, with the standard deviation being only 0.9 in Japan and less than 0.8 in Hong Kong and Taiwan. Yet this situation seems to reverse towards the end of secondary school; whereas inequality in mathematics achievement falls in England (to 0.95 of an international standard deviation by age 16) it increases in a number of East Asian countries (e.g. it is up from 0.80 at age 10 to 1.02 at age 16 in Hong Kong). Thus, although there is little change in average test scores between ages 10 and 16, the same does not appear to be true with regards educational 
inequality. In particular, whereas mathematics achievement seems to become more equal in England during secondary school, in the East Asian countries it becomes more dispersed ${ }^{14}$.

What is behind this apparent change in educational inequality? Table 4 panel A presents the $10^{\text {th }}$ percentile of the achievement distribution at the three ages. This reflects the math skills of the lowest achieving pupils within each of the 13 nations. Figure 3 illustrates how the $10^{\text {th }}$ percentile changes between primary and secondary school for England and East Asian nations. The left hand side refers to the age 10-14 comparison and the right hand side the age 10-16 comparison. The thin black line running through the centre of the bars represents the estimated $90 \%$ confidence interval. Interestingly, there is some evidence of an increase in P10 within England, particularly for the age 10 to age 16 comparison. In other words, the low achievers in England manage to improve relative to low achievers in other countries. The opposite is true, however, in Singapore, Hong Kong and Taiwan, where P10 declines (e.g. in Hong Kong P10 declines from -0.48 at age 10 to -0.72 at age 16). Consequently, one can see that between primary school and the end of secondary school, the gap between the lowest achieving children in England and the lowest achieving children in East Asian countries is reduced. This is consistent with government policy in England during this period, when a number of initiatives attempted to raise the basic skills of low achieving groups. However, it should be noted that, despite this progress, a significant gap remains between the lowest achievers in England and the lowest achievers in East Asia, even at age $16^{15}$.

\section{$<<$ Table $4>>$ \\ $<<$ Figure $3>>$}

Does the same hold true for the highest achieving children? In Table 4 panel $\mathrm{b}$ we provide analogous results for the $90^{\text {th }}$ percentile of the math achievement distribution (i.e. the test performance of the highest achieving children within each of the countries). Figure 4 then compares the change in the $90^{\text {th }}$ percentile between the end of primary school and the end of secondary school. Worryingly, it seems that England does lose some ground relative to its international competitors (and particularly the East Asian nations) in this respect. The bars in both the left and right hand panel of Figure 4 are negative for England, with the estimated

\footnotetext{
${ }^{14}$ Here we refer to inequality in educational outcomes (the spread of achievement) and not equality of opportunity (how achievement differs between socio-economic groups). The latter shall be the focus of the following sub-section.

${ }^{15}$ This can be seen in the right hand column of Table 4 panel A.
} 
90\% confidence interval not crossing zero. The implication is that the test score gap between the highest achieving children in England and the highest achieving children in the twelve other countries we consider increases ${ }^{16}$. On the other hand, the opposite is true in several of the East Asian countries - the highest achieving pupils tend to further extend their lead. For instance, Table $4 \mathrm{~b}$ reveals that the $90^{\text {th }}$ percentile in Hong Kong moves from 1.56 standard deviations above the cross-country mean at age 10 to 1.90 standard deviations at age 16 . Pulling these results together, Figure 4 suggests that the gap between the highest achieving children in England and the highest achieving children in East Asia increases between the end of primary school and the end of secondary school.

\section{$<<$ Figure $4>>$}

\subsection{Inequality of educational opportunity}

Finally, we turn to the issue of inequality of educational opportunity, defined as the difference in math test scores between high (more than 200 books) and low (25 or fewer books) socio-economic groups. Table 5 provides estimates at the three ages. It becomes immediately apparent that England has a particularly large socio-economic achievement gradient when measured in this way. For instance, at age 9/10 children from advantaged backgrounds score (on average) 0.87 standard deviations more on the TIMSS math test than children from disadvantaged backgrounds. This is bigger than any other country included in the analysis at the 5\% level (with the exception of Singapore). Moreover, no country has a significantly bigger socio-economic achievement gap than England at either age 13/14 or age 15/16. It is also interesting to note that there is no common pattern across the East Asian countries, with quite large socio-economic differences occurring regularly in some (e.g. Singapore, Taiwan) but not in others (e.g. Hong Kong).

\section{$<<$ Table 5 >}

Does the socio-economic test score gradient increase between ages 10 and 16 in England? Evidence on this issue can be found in Figure 5. This plots the socio-economic test score gap at the three ages. Children from advantaged backgrounds do indeed extend their lead over their disadvantaged peers in England, as has been found in previous research (Goodman et al 2009, Ermisch et al 2012). Although this increase of 0.26 of a standard

\footnotetext{
${ }^{16}$ It is important to once again stress that in this paper we are referring to relative differences between countries. Thus although English children's maths ability will clearly improve between the end of primary school and the end of secondary school, this may be at a slower rate than their East Asian peers (and hence be in relative decline).
} 
deviation (from 0.87 at age 10 to 1.13 at age 16 ) is statistically significant $(t=2.5, p=0.01)^{17}$ and of reasonable magnitude, the vast majority of socio-economic inequality in educational achievement is nevertheless apparent by age 10. Moreover, Figure 5 would seem to suggest that the socio-economic gradient also increases in the four East Asian countries by roughly the same (Singapore, Japan) or even greater (Hong Kong, Taiwan) amounts.

\section{$<<$ Figure $5>>$}

Thus although we have replicated previous findings of an increasing socio-economic achievement gradient between ages 10 and 16 in England, we have also presented evidence that suggests the same holds true in the leading East Asian nations. As inequality in educational achievement is already large before children finish primary school, this further suggests that public investment into increasing opportunities for young people from disadvantaged homes may be best placed in the early years (Cunha et al 2006).

\section{Discussion, policy recommendations and conclusions}

The Programme for International Student Assessment (PISA) and Trends in Mathematics and Science Study (TIMSS) are two highly respected studies of school pupils' academic achievement. Policymakers have shown great interest in their findings - particularly the dominance of East Asian countries towards the top of the PISA and TIMSS rankings. The Secretary of State for Education, Michael Gove, and his shadow, Stephen Twigg, have both suggested that England must learn lessons from these high performing jurisdictions, including policies that could be successfully implemented in this country. We have provided some guidance on this issue by attempting to identify the age at which children in England are overtaken by their peers in East Asia (in terms of average mathematics test scores), and thus where efforts to reform the schooling system should be concentrated. This leads us to the following three policy recommendations.

Firstly, policymakers should concentrate on reforming mathematics education in the early primary and pre-school years. This paper has shown how there is a large gap in math achievement between England and leading East Asian nations even at age 10, but also that this gap does not appreciably widen during secondary school. Thus, despite major policy focus on secondary schools, there is little evidence that these institutions are responsible for England's disappointing position in the PISA and TIMSS rankings. What policies from East

\footnotetext{
${ }^{17}$ Statistical significance based upon a two-sample t-test with independent samples.
} 
Asian countries could England adopt to boost math skills before the end of primary school? Unfortunately, the answer does not seem to be straightforward. One might suggest that there is a need for government to provide more (and higher quality) pre-school care, as there is evidence that this has a positive impact upon children's later academic achievement (Cunha et al 2006). However, pre-school enrolment rates are already higher in England than Japan, Singapore, Taiwan and Hong Kong (recall Table 1). Moreover, although we are unable to compare pre-school quality, it is interesting to note that the OECD has recently suggested that certain East Asian nations should learn lessons from the UK in this respect (Taguma et al., 2012). Investment in education also seems unlikely to be the cause, as the percentage of GDP per capita spent on education has been consistently lower in the East Asian countries than the UK during the 1999-2009 period (World Bank 2012). Primary school class sizes also tend to be larger in East Asia and instructional hours lower (OECD 2011a). However, one factor that does notably differ is the quality and status of teachers. For instance, teachers in East Asia tend to be high academic performers (OECD 2011a), and have a duty to study and research, aswell as teach (Jensen et al. 2012). Moreover, they receive high earnings both in comparative international terms and relative to other professional groups. Although establishing the causal impact of this higher pay and status is beyond the scope of this paper, we do suggest that raising the prestige of teaching (particularly at the primary school level) could be an important lever upon which English policymakers may draw. Consequently, further research should be devoted for understanding the impact of different school-level educational resources. Our results, based on the mathematics competence and however limited, are nevertheless valuable for pointing out these analyses should principally focus on the pre-primary and primary levels.

Our second recommendation calls for further investment in the skills of children from disadvantaged backgrounds, again with a focus on the primary and pre-school years. Section 3.3 illustrates that the socio-economic gradient in math test scores seem to be steeper in England than East Asian countries. While this gap may widening slightly in England during secondary school, socio-economic differences in academic achievement are largely in place by age 10. Although some caution is required when interpreting this result, given the limitations of the data available (Jerrim and Micklewright 2012), we note that our findings (and subsequent policy recommendation) are consistent with a host of other academic research (e.g. Schütz et al 2008, Jerrim and Micklewright 2011, Cunha et al 2006, Heckman 2007). As primary education is free or nearly free in England and most East Asian countries, 
alternative explanations for the large socio-economic achievement gradient in England must be sought. One possibility is that ability grouping in primary school mathematics classes is relatively common in England, but not East Asia (Boaler et al. 2011, OECD 2012) ${ }^{18}$. As Gamoran (2004) and OECD (2012) note, there is little evidence that such streaming improves average performance, but may exacerbate test score differences between advantaged and disadvantaged groups. Similarly, between school selection processes are weaker in East Asian countries than England (OECD 2012), meaning that disadvantaged children are likely to have better access to quality educational resources. Reducing the segregation of pupils in England, both within and between primary schools, may thus make an important contribution to narrowing the socio-economic achievement gap in mathematics.

Finally, although we maintain that policymakers should focus on the earlier stages of young people's educational career, some important changes are needed to improve aspects of mathematics provision during secondary school. The most pressing issue is to ensure that the curriculum stretches the best young mathematicians enough, and that they are motivated (and incentivised) to fully develop their already accumulated academic skill. Evidence presented in this paper has suggested that the gap between the highest achieving children in England and the highest achieving children in East Asia widens between ages 10 and 16 (at least in mathematics). This is something that needs to be corrected as highly skilled individuals are likely to be important for the continuing success of certain major British industries (e.g. financial services) and to foster the technological innovation needed for long-run economic growth (Bean and Brown 2005, Toner 2011). One possible explanation for this finding is the widespread use of private tuition by East Asian families for both remedial and enrichment purposes (Ono, 2007; Sohn et al., 2010). This helps to boost the performance of all pupils, including those already performing well at school. In comparison, private tutoring in England is mainly undertaken by a relatively small selection of children from affluent backgrounds, often for remedial purposes. While a large proportion of East Asian families are willing to personally finance such activities through the private sector, the same is unlikely to hold true in the foreseeable future within England. Consequently, the state may need to intervene. Gifted and talented schemes, a shift of school and pupil incentives away from reaching floor targets (e.g. a C grade in GCSE mathematics) and enhanced tuition for children who excel in school are all possible policy responses.

\footnotetext{
${ }^{18}$ Hallam and Parsons (2012) show that one in six UK children are being taught in ability streams at age 7.
} 
These recommendations do, however, come with important caveats. Firstly, although it is true that most of East Asia's modern educational systems 'were strongly and deliberately modelled after the Western educational rubric (Jeynes, 2008: 900)' the identification of successful policies in some countries does not necessarily ensure the success of their implementation in others. Even when policies and teaching methods have been proven to be effective in East Asia, culture and context potentially limits the extent to which such initiatives can be successfully transferred to other countries (Cowen, 2006). Secondly, it is worth underlining that cultural and social factors might be behind these countries strong PISA and TIMSS test performance. In East Asian cultures, education has historically been considered a highly valued good and the main legitimate method for social mobility. This can be seen not only in the East Asian teachers' high salaries, but also by the heavy investment of families in private tutoring services. Family and social commitment to education is also reflected in the large number of weekly hours East Asian students spend in self-study activities and, as Zhu and Leung (2011) argue, the great impact extrinsic motivation has on their mathematics test performance (much more so than their Western peers). Consequently, the implementation of some of the characteristics of the East Asian educational model may imply the need for a cultural shift towards greater belief in the value of education amongst all and the importance of a hard work ethic. Indeed, it is important for academics and policymakers to recognise that East Asian children vastly out-perform their English peers even when they have been through the English schooling system ${ }^{19}$. This is perhaps the clearest indication that it is actually what happens outside of school that is driving these countries superior PISA and TIMSS math test performance. We recognise, of course, that such cultural shifts cannot be expected to take place in England in the short run, as it is notoriously difficult to modify people's attitudes and beliefs. Similarly, although such policies can lead to higher academic performance, they have well known side effects, such as the pressure which students (physical and psychological) and parents (financial) must put up with (Bray 2003). Yet, in an increasingly competitive world, such a cultural shift may be necessary to ensure England's future prosperity and long-run economic success.

\footnotetext{
${ }^{19}$ In $2011,78.5 \%$ of Chinese children achieved 5 or more $\mathrm{A}^{*}$ - C grades including math and English. This $\begin{array}{llllll}\text { compares to a } & \text { a } & \text { national } & \text { average } & \text { See }\end{array}$ http://www.education.gov.uk/rsgateway/DB/SFR/s001057/index.shtml
} 


\section{References}

Ammermueller, A. (2006) Educational opportunities and the role of institutions, ZEW Discussion Paper, 05 (44), 1 - 50.

Ammermueller A. \& Pischke J. (2009) Peer effects in European primary schools: Evidence from the Progress in International Reading Literacy Study, Journal of Labor Economics, 27 (3), 315-348.

Barro, J. (2001) Human capital and growth, American Economic Review, 91 (2), 12-17.

Bean, F. \& Brown S. (2005) A canary in the mineshaft? International graduate enrollments in science and engineering in the United States. Available online at:

www.utexas.edu/cola/centers/european studies/files/pdf/immigration-policy-conference/bean.pdf (accessed 30 May 2012).

Boaler, J. Altendorff, L. \& Kent, J. (2011) Mathematics and science inequalities in the United Kingdom: when elitism, sexism and culture collide, Oxford Review of Education, 37 (4), 457-484.

Bray, M. (2003) Adverse effects of private supplementary tutoring: Dimensions, implications and government responses (Paris, International Institute for Educational Planning).

Brown, G. Micklewright, J. Schnepf, S. \& Waldmann, R. (2007) International surveys of educational achievement: How robust are the findings?, Journal of the Royal Statistical Society Series A, 170 (3), 623-646.

Brunello, G. Weber, G. \& Weiss, C (2012) Books are forever: Early Life Conditions, Education and Lifetime Income, IZA Discussion Paper 6386.

Cowen, R. (2006) Acting comparatively upon the educational world: Puzzles and possibilities, Oxford Review of Education, 32 (5), 561-573.

Cunha, F. Heckman, J. \& Lochner, L. (2006) Interpreting the Evidence on Life Cycle Skill Formation, in: E. Hanushek \& F. Welch (Eds) Handbook of the Economics of Education (Amsterdam, Holland North).

Department for Education (2011) Review of the national curriculum in England: What can we learn from the English, mathematics and science curricula of high-performing jurisdictions? Available online at: https://www.education.gov.uk/publications/standard/publicationDetail/Page1/DFE-RR178 (accessed 10 March 2012).

Ermisch, J. \& Del Bono, E. (2012) Inequality in achievements during adolescence, in: J. Ermisch, M. Jantti, \& T. Smeeding, (Eds) Inequality from childhood to adulthood: A cross-national perspective on the transmission of advantage (New York, Russell Sage Foundation).

Ermisch, J. Jantti, M. \& Smeeding, T. (2012) Inequality from childhood to adulthood: A crossnational perspective on the transmission of advantage (New York, Russell Sage Foundation).

Evans, M. Kelley J. Sikora J. \& Treiman, D. (2010) Family scholarly culture and educational success: books and schooling in 27 nations, Research in Social Stratification and Mobility, 28 (2), 171-197.

Ferreira, F. \& Gignoux, G. (2011) The measurement of educational inequality: Achievement and opportunity, IZA Discussion Paper 6161.

Gamoran, A. (2004) Classroom organization and instructional quality, in: H. Walberg, A. Reynolds \& M. Wang (Eds) Can unlike students learn together? Grade retention, tracking and grouping (Greenwich, Information Age). 
Goodman, A. Sibieta, L. \& Washbook, E. (2009) Inequalities in educational outcomes among children aged 3 to 16. Available online at:

http://sta.geo.useconnect.co.uk/pdf/Inequalities\%20in\%20education\%20outcomes\%20among\%20chil dren.pdf (accessed 6 February 2012).

Hallam, S. \& Parsons, S. (2012) Prevalence of streaming in UK primary schools: evidence from the Millennium Cohort Study, British Educational Research Journal, DOI:

10.1080/01411926.2012.659721

Hanushek, E. \& Wößmann, L. (2006) Does educational tracking affect performance and inequality? Differences in differences evidence across countries, Economic Journal, 116 (510), C63 - C76.

Hanushek, E. \& Wößmann, L. (2008) The role of cognitive skills in economic development, Journal of Economic Literature, 46 (3), 607 - 668.

Hanushek, E \& Wößmann, L. (2010) The economics of international differences in educational achievement, IZA Discussion Paper 4925.

Heckman, J. (2007) The economics, technology, and neuroscience of human capability formation, Proceedings of the National Academy of Sciences, 104 (3), 13250-13255.

Hermann, Z. \& Horn, D. (2011) How are inequality of opportunity and mean student performance are related? A quantile regression approach using PISA data, IEHAS Discussion Papers 1124.

Jakubowski, M. (2010) Effects of tracking on achievement growth: exploring difference-indifferences approach to PIRLS, TIMSS and PISA data, in J. Dronkers (Ed) Quality and Inequality of Education (Netherlands, Springer).

Jensen, B. Hunter, A. Sonnemann, J. \& Burns, T. (2012) Catching up: Learning from the best school systems in East Asia. Available online at: http://grattan.edu.au/publications/reports/post/catching-uplearning-from-the-best-school-systems-in-east-asia/ (accessed 11 November 2011).

Jerrim, J. (2012) The socio-economic gradient in teenagers' literacy skills: how does England compare to other countries?, Fiscal Studies, 33 (2).

Jerrim, J. \& Micklewright, J. (2011) Children's cognitive ability and parents' education: distinguishing the impact of mothers and fathers, in T. Smeeding, R. Erikson \& M. Jantti (Eds) Persistence, privilege and parenting: The comparative study of intergenerational mobility (New York, Russell Sage Foundation).

Jerrim, J. \& Micklewright, J. (2012a) Parental socio-economic status and children's cognitive achievement at ages 9 and 15: how do the links vary across countries? in: J. Ermisch, M. Jantti, \& T. Smeeding, (Eds) Inequality from childhood to adulthood: A cross-national perspective on the transmission of advantage (New York, Russell Sage Foundation).

Jerrim, J. \& Micklewright, J. (2012b) The socio-economic gradient in children's cognitive skills: How robust are comparisons across countries to who reports the socio-economic characteristics?, DoQSS working paper.

Jeynes, W. (2008) What we should and should not learn from the Japanese and other East Asian education systems, Educational Policy, 22 (6), 900-927.

Machin, S. (2009) Inequality and education, in W. Salverda, B. Nolan \& T. Smeeding (Eds) The Oxford Handbook of Economic Inequality (Oxford, Oxford University Press). 
Micklewright, J. \& Schnepf, S. (2006) Response bias in England in PISA 2000 and 2003. Available online at: https://www.education.gov.uk/publications/eOrderingDownload/RR771.pdf (accessed 23 June 2011).

OECD (2009) PISA data analysis manual: SPSS second edition (Paris, OECD).

OECD (2010) The High Cost of Low Educational Performance (Paris, OECD).

OECD (2011a) Education at a Glance 2011 (Paris, OECD).

OECD (2011b) PISA 2009 Technical Report (Paris, OECD).

OECD (2012) Equity and quality in education: Supporting disadvantaged students and schools (Paris, OECD).

Olson, J. Martin, M. \& Mullis, I. (2008) TIMSS 2007 Technical Report (Boston, Boston College).

Ono, H. (2007) Does examination hell pay off? A cost-benefit analysis of "ronin" and college education in Japan, Economics of Education Review, 26 (3), 271-284.

Schütz G. Ursprung, H. \& Wößmann, L. (2008) Education policy and equality of opportunity, Kyklos, 61 (2), 279-308.

Sohn, H. Lee, D. Jang, S. \& Kim, T. K. (2010) Longitudinal relationship among private tutoring, student-parent conversation, and student achievement, KEDI Journal of Educational Policy, 7 (1), 23 41.

Taguma, M. Litjens, I. Kim, J. H. \& Malowiecki, K. (2012) Quality matters in early childhood education and care: Korea (Paris, OECD).

Toner, P. (2011) Workforce skills and innovation: An overview of major themes in the literature, OECD Education Working Papers number 55.

Waldinger, F. (2007) Does ability tracking exacerbate the role of family background for students' test scores? Available online at:

http://www2.warwick.ac.uk/fac/soc/economics/staff/academic/waldinger/research/ability_tracking.pdf (accessed 19 October 2011).

Wößmann, L. (2008) How equal are educational opportunities? Family background and student achievement in Europe and the United States, Zeitschrift für Betriebswirtschaft, 78 (1), 45-70.

World Bank (2012) World Development Indicators (Washington DC, World Bank).

Zhu, Y. \& Leung, F. (2011) Motivation and achievement: is there an East Asian model?, International Journal of Science and Mathematics Education, 9 (5), 1189-1212. 
Table 1. Key characteristics of the UK, Japan, Singapore, Hong Kong and Taiwan

\begin{tabular}{|c|c|c|c|c|c|}
\hline & Japan & $\begin{array}{l}\text { Hong } \\
\text { Kong } \\
\end{array}$ & Singapore & Taiwan & $\begin{array}{r}\text { United } \\
\text { Kingdom } \\
\end{array}$ \\
\hline 1. GDP per capita (PPP 2005 US \$000) & 32.0 & 36.3 & 47.3 & 28.7 & 33.4 \\
\hline $\begin{array}{l}\text { 2. \% GDP spent on education (2009) } \\
\text { 3. Enrolment rates in pre-primary education }\end{array}$ & 3.8 & 4.8 & 3.1 & 4.1 & 5.4 \\
\hline (\%) & 90 & 97 & - & 29 & 81 \\
\hline 4. Enrolment rate: primary education $(\%)$ & 100 & 92 & - & 98 & 100 \\
\hline 5. Enrolment rates: secondary education (\%) & 99 & 76 & - & 95 & 96 \\
\hline 6. Enrolment rate: higher education (\%) & 59 & 57 & - & 82 & 59 \\
\hline 7. Mean PISA math score (2009) & $529(94)$ & $555(95)$ & $562(104)$ & $543(105)$ & $492(87)$ \\
\hline 8. Mean PISA reading score (2009) & $520(100)$ & $533(84)$ & $526(97)$ & $495(86)$ & $494(95)$ \\
\hline 9. Mean PISA science score (2009) & $539(100)$ & $549(87)$ & $542(104)$ & $520(87)$ & $514(99)$ \\
\hline
\end{tabular}

Sources:

1 Pennworld Tables (https://pwt.sas.upenn.edu/php_site/pwt_index.php).

2 to 6 World Development Indicators and Taiwan, from Ministry of Education. Data refers to 2009.

7 to 9 PISA survey website (http://www.oecd.org/pisa/46643496.pdf)Notes:

In brackets, standard deviation.

PISA 2009 scores for England and Scotland were, respectively: 493 (87) and 499 (93) in math; 495 (95) and 500 (94), in reading; 515 (99) and 514 (96) in science. 
Table 2. Average math test scores at ages 9/10, 13/14 and 15/16 (international z-scores)

\begin{tabular}{lccllllll}
\hline & \multicolumn{2}{c}{ Age 9/10 } & \multicolumn{3}{c}{ Age 13/14 } & \multicolumn{2}{c}{ Age 15/16 } \\
& Mean & SE & & Mean & SE & & Mean & SE \\
\hline Singapore & $0.820^{*}$ & 0.062 & Taiwan & $0.904^{*}$ & 0.050 & Singapore & $0.729 *$ & 0.056 \\
Hong Kong & $0.570^{*}$ & 0.037 & Singapore & $0.844^{*}$ & 0.062 & Hong Kong & $0.644^{*}$ & 0.053 \\
Japan & $0.446^{*}$ & 0.023 & Hong Kong & $0.599^{*}$ & 0.078 & Taiwan & $0.521^{*}$ & 0.059 \\
Taiwan & $0.435^{*}$ & 0.026 & Japan & $0.571^{*}$ & 0.040 & Japan & $0.371^{*}$ & 0.057 \\
Lithuania & 0.064 & 0.041 & England & -0.072 & 0.064 & Australia & $0.215^{*}$ & 0.032 \\
Russia & 0.037 & 0.051 & Russia & $-0.103^{*}$ & 0.041 & Slovenia & 0.070 & 0.060 \\
England & 0.035 & 0.053 & USA & $-0.130^{*}$ & 0.035 & Norway & 0.032 & 0.025 \\
USA & $-0.128^{*}$ & 0.034 & Lithuania & $-0.166^{*}$ & 0.038 & Scotland & 0.004 & 0.047 \\
Italy & $-0.326^{*}$ & 0.047 & Slovenia & $-0.219^{*}$ & 0.025 & England & -0.016 & 0.041 \\
Australia & $-0.375^{*}$ & 0.052 & Australia & $-0.278^{*}$ & 0.057 & USA & -0.077 & 0.046 \\
Scotland & $-0.473^{*}$ & 0.042 & Scotland & $-0.379^{*}$ & 0.054 & Italy & $-0.121^{*}$ & 0.029 \\
Slovenia & $-0.623^{*}$ & 0.033 & Italy & $-0.477^{*}$ & 0.035 & Lithuania & $-0.193^{*}$ & 0.042 \\
Norway & $-0.959^{*}$ & 0.031 & Norway & $-0.596^{*}$ & 0.023 & Russia & $-0.285^{*}$ & 0.038 \\
\hline
\end{tabular}

Notes:

$1 *$ indicates where average test scores are statistically different from 0 at the $5 \%$ level. This illustrates whether average math test scores are significantly different from the 13 country cross-national average. 3 All standard errors take into account the clustering of children within schools.

2 Age 9/10 refers to TIMSS $20034^{\text {th }}$ grade data, age 13/14 is TIMSS $20078^{\text {th }}$ grade and age 15/16 PISA 2009.

3 All figures presented are international z-scores. 
Table 3. Change in average math test scores between primary and secondary school

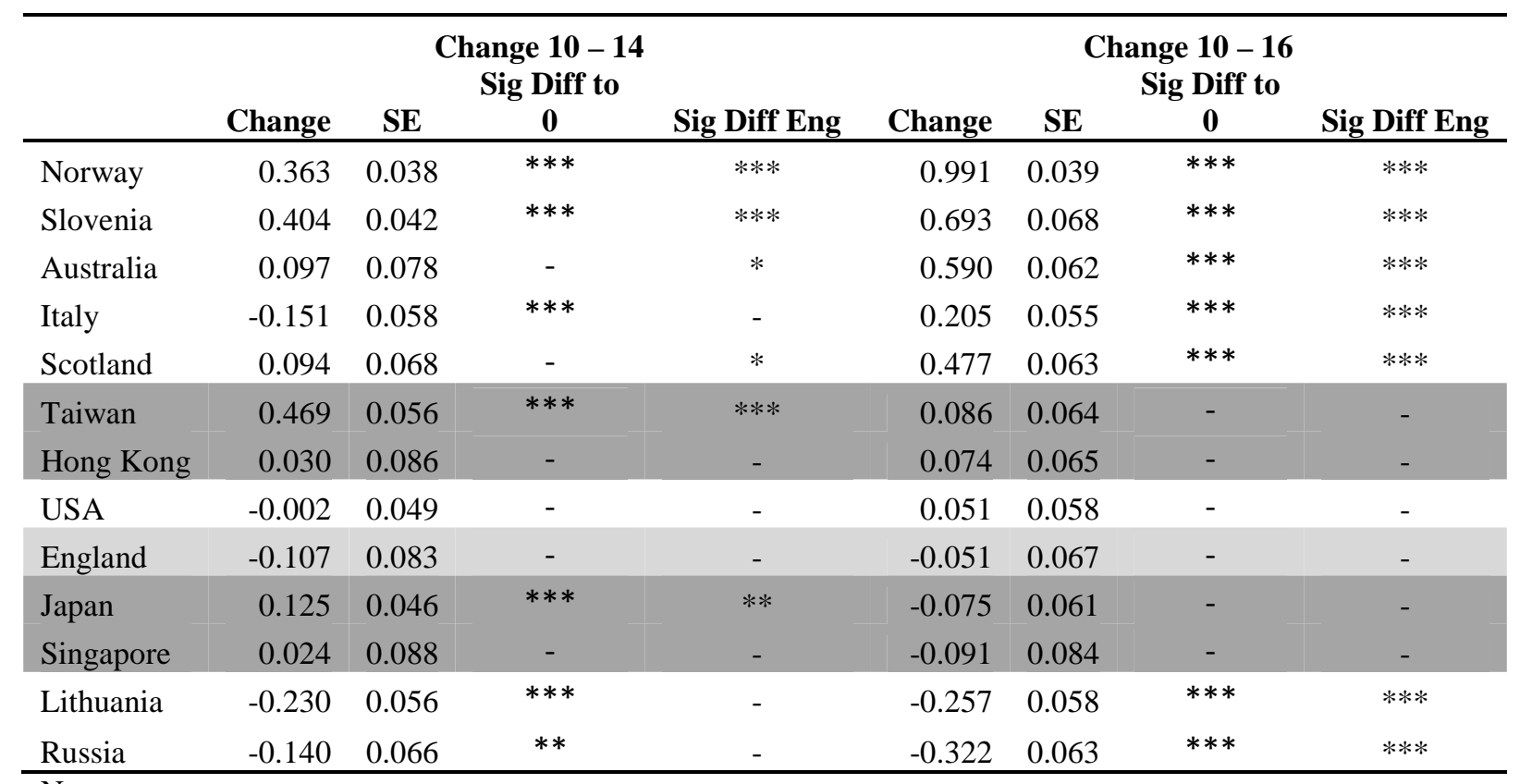

Notes:

$1 * * *$ and $* * *$ indicate statistical significance at the $10 \%, 5 \%$ and $1 \%$ level. 'Sig Diff to 0' illustrates whether the change in average math test scores are significantly different from the change for the 13 country crossnational average (using a two sample t-test with independent surveys). 'Sig Diff Eng' illustrates whether the change in average math test scores are significantly different from the change seen in England (using a two sample t-test assuming independence between countries). 3 All standard errors take into account the clustering of children within schools.

2 The left hand columns refer to the change in average math test scores between age 10 (TIMSS 2003 data) and age 14 (TIMSS 2007 data). The right hand columns refer to the change in average math test scores between age 10 (TIMSS 2003 data) and age 16 (PISA 2009 data).

3 All figures presented are international z-scores. 
Table 4. The estimated $10^{\text {th }}$ and $90^{\text {th }}$ percentile of the math test score distribution at ages 9/10, 13/14 and 15/16 (international z-scores)

(a) Test scores at the $10^{\text {th }}$ Percentile

\begin{tabular}{lcclllllll}
\hline & \multicolumn{2}{c}{ Age 9/10 } & \multicolumn{2}{c}{ Age 13/14 } & \multicolumn{2}{c}{ Age 15/16 } \\
& P10 & SE & & P10 & SE & & P10 & SE \\
\hline Hong Kong & -0.48 & 0.048 & Singapore & -0.66 & 0.093 & Hong Kong & -0.72 & 0.076 \\
Singapore & -0.56 & 0.111 & Japan & -0.70 & 0.041 & Singapore & -0.79 & 0.051 \\
Taiwan & -0.57 & 0.034 & Taiwan & -0.84 & 0.078 & Japan & -0.92 & 0.076 \\
Japan & -0.76 & 0.029 & Hong Kong & -0.93 & 0.198 & Taiwan & -0.94 & 0.050 \\
Lithuania & -1.21 & 0.071 & USA & -1.28 & 0.048 & Australia & -1.08 & 0.034 \\
Russia & -1.22 & 0.062 & Slovenia & -1.32 & 0.031 & Norway & -1.14 & 0.032 \\
USA & -1.39 & 0.044 & Lithuania & -1.36 & 0.042 & England & -1.23 & 0.044 \\
England & -1.41 & 0.052 & Russia & -1.39 & 0.050 & Slovenia & -1.24 & 0.043 \\
Italy & -1.69 & 0.053 & England & -1.38 & 0.074 & Scotland & -1.27 & 0.049 \\
Australia & -1.73 & 0.076 & Australia & -1.48 & 0.084 & USA & -1.33 & 0.056 \\
Scotland & -1.74 & 0.060 & Italy & -1.61 & 0.056 & Italy & -1.40 & 0.040 \\
Slovenia & -1.93 & 0.037 & Norway & -1.61 & 0.031 & Lithuania & -1.41 & 0.040 \\
Norway & -2.30 & 0.049 & Scotland & -1.63 & 0.052 & Russia & -1.44 & 0.037 \\
\hline
\end{tabular}

(b) Test scores at the $90^{\text {th }}$ Percentile (international z-scores)

\begin{tabular}{lccllllll}
\hline & \multicolumn{2}{c}{ Age 9/10 } & \multicolumn{2}{c}{ Age 13/14 } & \multicolumn{2}{c}{ Age 15/16 } \\
& P90 & SE & & P90 & SE & & P90 & SE \\
\hline Singapore & 2.08 & 0.064 & Taiwan & 2.33 & 0.054 & Singapore & 2.12 & 0.074 \\
Hong Kong & 1.56 & 0.045 & Singapore & 2.14 & 0.067 & Hong Kong & 1.90 & 0.050 \\
Japan & 1.58 & 0.043 & Hong Kong & 1.85 & 0.061 & Taiwan & 1.94 & 0.064 \\
Taiwan & 1.41 & 0.027 & Japan & 1.80 & 0.067 & Japan & 1.67 & 0.060 \\
England & 1.41 & 0.048 & England & 1.15 & 0.072 & Australia & 1.51 & 0.040 \\
Russia & 1.29 & 0.081 & Russia & 1.12 & 0.043 & Slovenia & 1.41 & 0.078 \\
Lithuania & 1.21 & 0.044 & USA & 1.02 & 0.041 & Scotland & 1.29 & 0.060 \\
USA & 1.07 & 0.031 & Lithuania & 1.02 & 0.049 & Norway & 1.21 & 0.033 \\
Italy & 0.94 & 0.063 & Australia & 0.91 & 0.096 & England & 1.20 & 0.052 \\
Australia & 0.86 & 0.059 & Slovenia & 0.86 & 0.032 & USA & 1.20 & 0.050 \\
Scotland & 0.74 & 0.052 & Scotland & 0.81 & 0.052 & Italy & 1.14 & 0.026 \\
Slovenia & 0.56 & 0.051 & Italy & 0.62 & 0.044 & Lithuania & 1.01 & 0.057 \\
Norway & 0.31 & 0.028 & Norway & 0.37 & 0.019 & Russia & 0.87 & 0.059 \\
\hline Notes: & & & & & & & &
\end{tabular}

Notes:

1 Age $9 / 10$ refers to TIMSS $20034^{\text {th }}$ grade data, age 13/14 is TIMSS $20078^{\text {th }}$ grade and age $15 / 16$ PISA 2009.

2 All figures presented are international z-scores.

3 All standard errors take into account the clustering of children within schools. See Appendix 1 for further details on calculation of standard errors. 
Table 5. Socio-economic differences in children's math test scores at age 10, 14 and 16 (international z-scores)

\begin{tabular}{lcccccc}
\hline & \multicolumn{2}{c}{ Age 10 } & \multicolumn{2}{c}{ Age 14 } & \multicolumn{2}{c}{ Age 16 } \\
& Beta & SE & \multicolumn{1}{c}{ Beta } & SE & \multicolumn{1}{c}{ Beta } & \multicolumn{1}{c}{ SE } \\
\hline Singapore & 0.882 & 0.079 & 0.939 & 0.093 & 0.999 & 0.082 \\
England & 0.871 & 0.087 & 1.141 & 0.082 & 1.126 & 0.052 \\
USA & $0.680^{*}$ & 0.044 & $0.782^{*}$ & 0.043 & 1.051 & 0.057 \\
Australia & $0.612^{*}$ & 0.095 & $0.853^{*}$ & 0.079 & 1.063 & 0.041 \\
Scotland & $0.582^{*}$ & 0.080 & 0.963 & 0.075 & 1.211 & 0.078 \\
Japan & $0.566^{*}$ & 0.062 & $0.722^{*}$ & 0.070 & $0.692^{*}$ & 0.057 \\
Taiwan & $0.533^{*}$ & 0.039 & 1.046 & 0.063 & 1.047 & 0.066 \\
Norway & $0.513^{*}$ & 0.074 & $0.648^{*}$ & 0.038 & 1.007 & 0.045 \\
Lithuania & $0.489^{*}$ & 0.075 & $0.798^{*}$ & 0.067 & $0.948^{*}$ & 0.061 \\
Russia & $0.422^{*}$ & 0.093 & $0.677^{*}$ & 0.074 & $0.700^{*}$ & 0.063 \\
Hong Kong & $0.335^{*}$ & 0.088 & $0.652^{*}$ & 0.116 & $0.865^{*}$ & 0.083 \\
Slovenia & $0.266^{*}$ & 0.084 & $0.686^{*}$ & 0.051 & 1.130 & 0.096 \\
Italy & $0.115^{*}$ & 0.077 & $0.637^{*}$ & 0.057 & $0.913^{*}$ & 0.045 \\
\hline
\end{tabular}

Notes:

1 Authors' calculations based upon the regression model presented in section 2.

2 Figures refer to the difference in average test scores between children with few $(0-25)$ versus children with many (more than 200) books.

3 All figures presented in terms of international z-scores.

$4 *$ indicates where socio-economic gradient significantly different to England at the 5\% level. All standard errors take into account the clustering of children within schools. 
Figure 1. Average math test scores at ages 9/10, 13/14 and 15/16 - England compared to a selection of East Asian countries

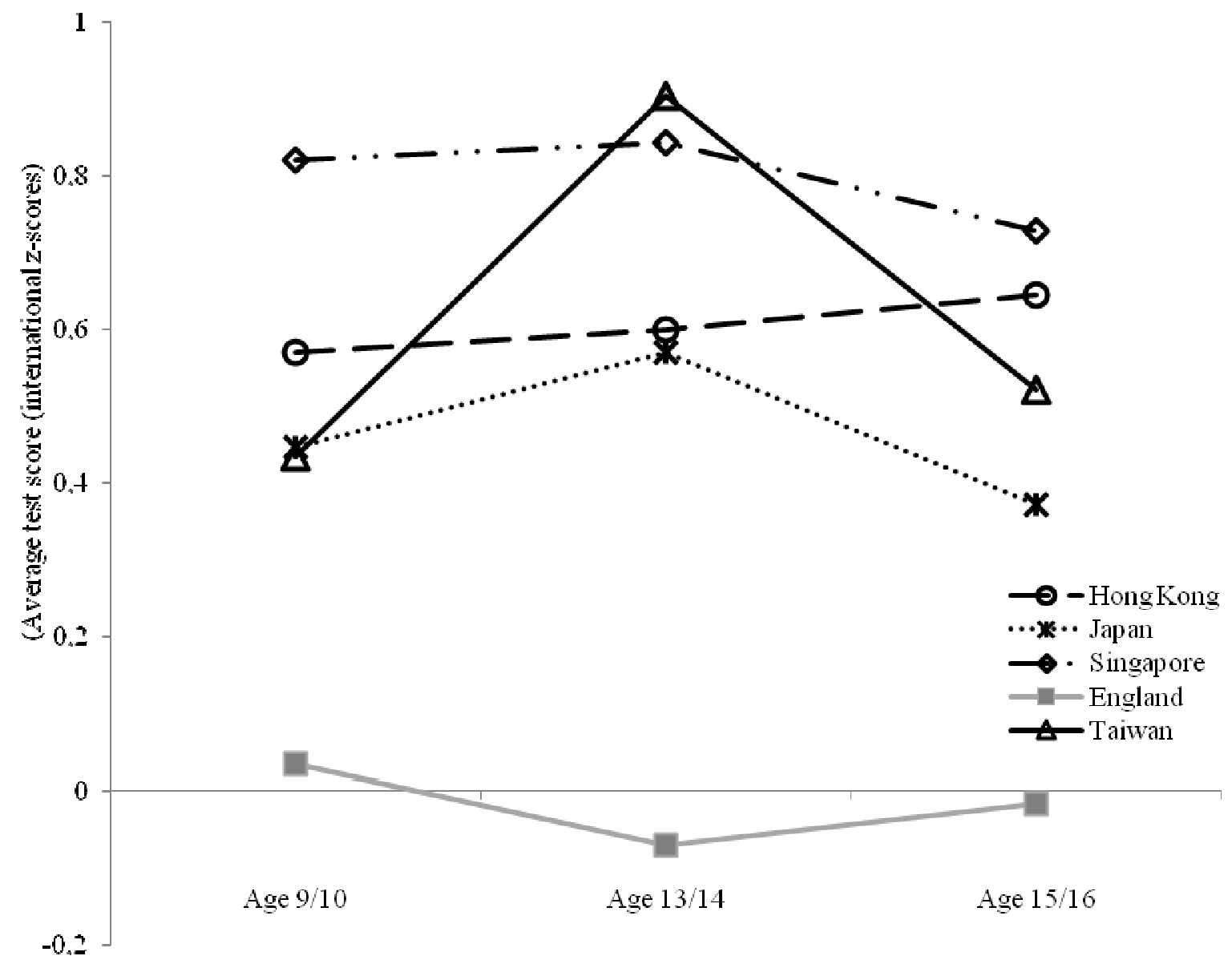

Notes:

1 Age $9 / 10$ refers to TIMSS $20034^{\text {th }}$ grade data, age $13 / 14$ refers to TIMSS $20078^{\text {th }}$ grade data and age $15 / 16$ refers to PISA 2009.

2 All figures presented in terms of international z-scores. 
Figure 2. Standard deviation of mathematics test scores (inequality in math outcomes)

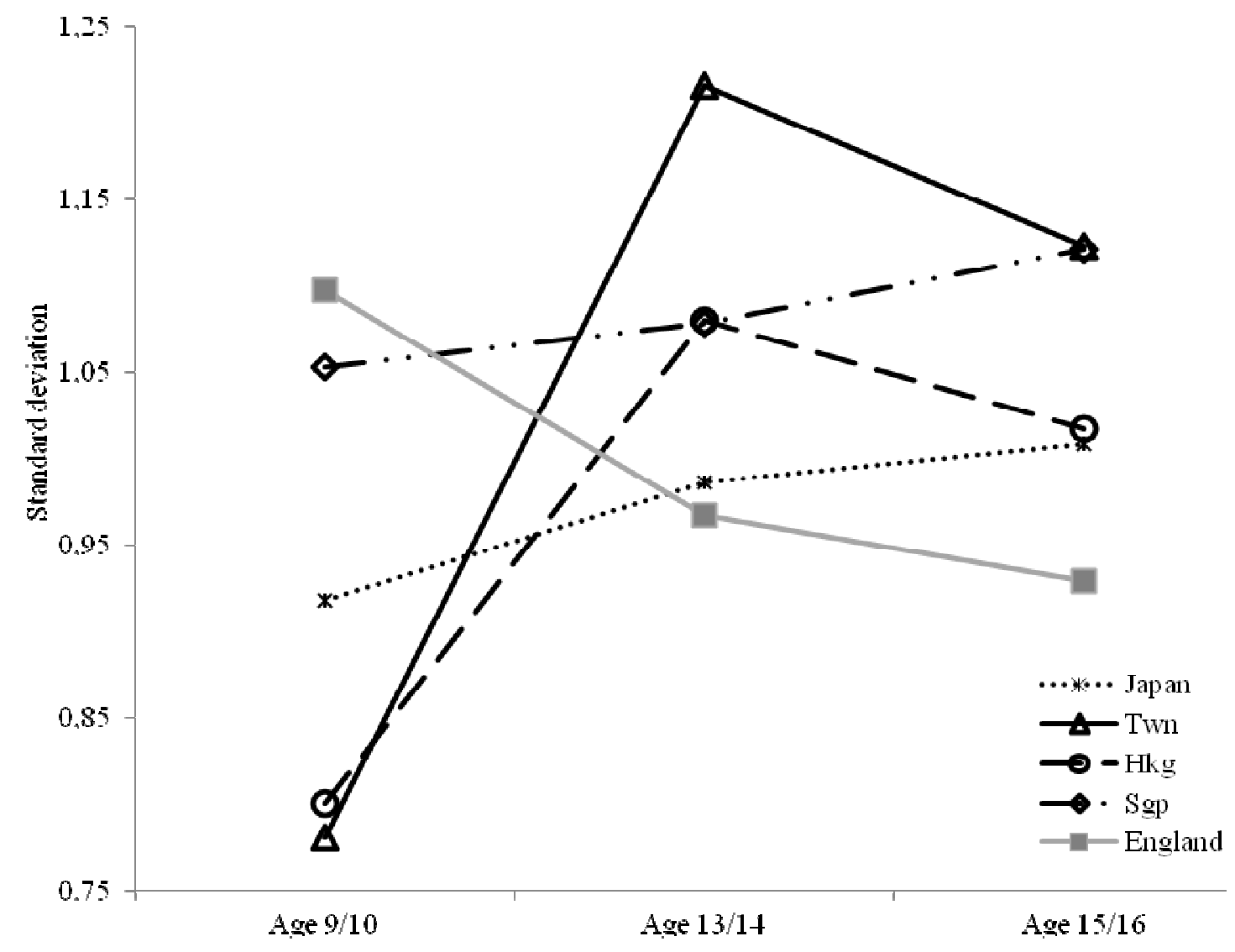

Notes:

1 Age $9 / 10$ refers to TIMSS $20034^{\text {th }}$ grade data, age $13 / 14$ refers to TIMSS $20078^{\text {th }}$ grade data and age $15 / 16$ refers to PISA 2009.

2 All figures presented in terms of international z-scores. 
Figure 3. Change in the $10^{\text {th }}$ percentile of the math test distribution between the end of primary school and secondary school

(a) Age 9/10 to $13 / 14$

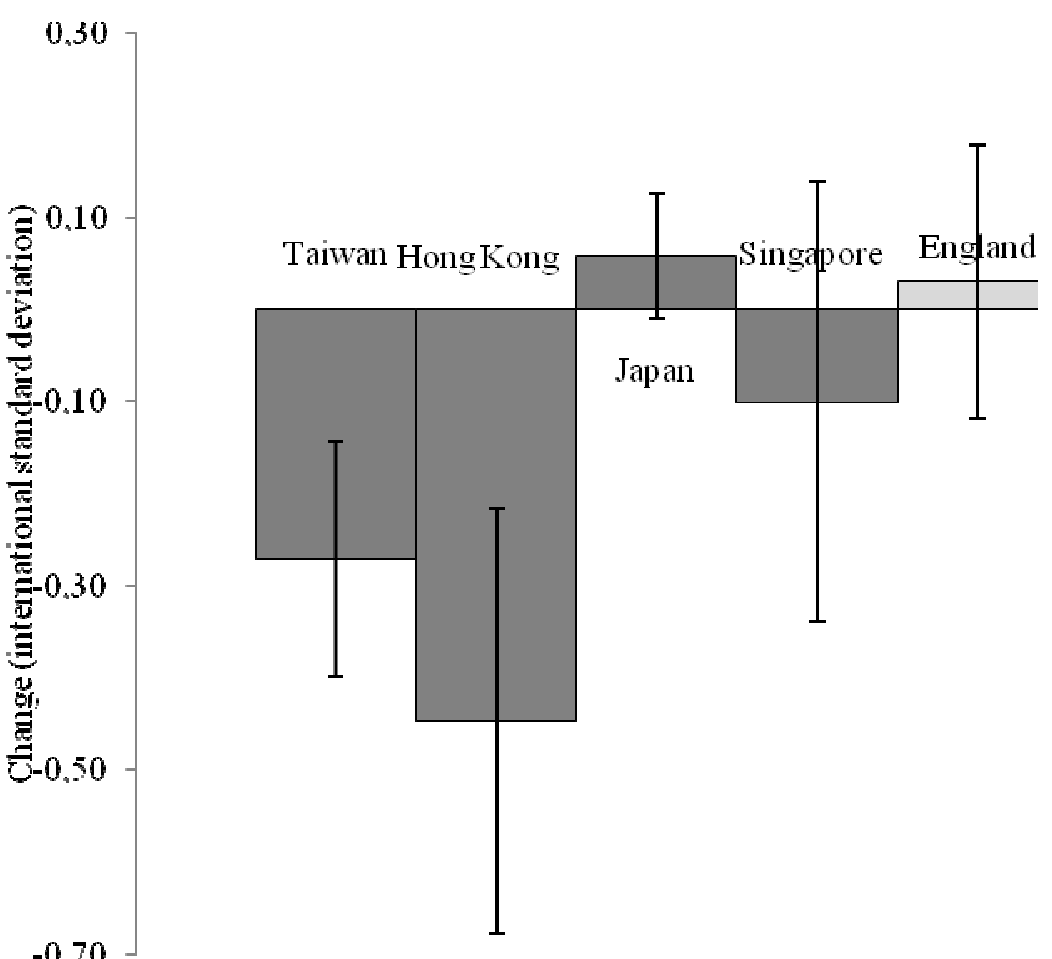

(b) Age 9/10 to $15 / 16$

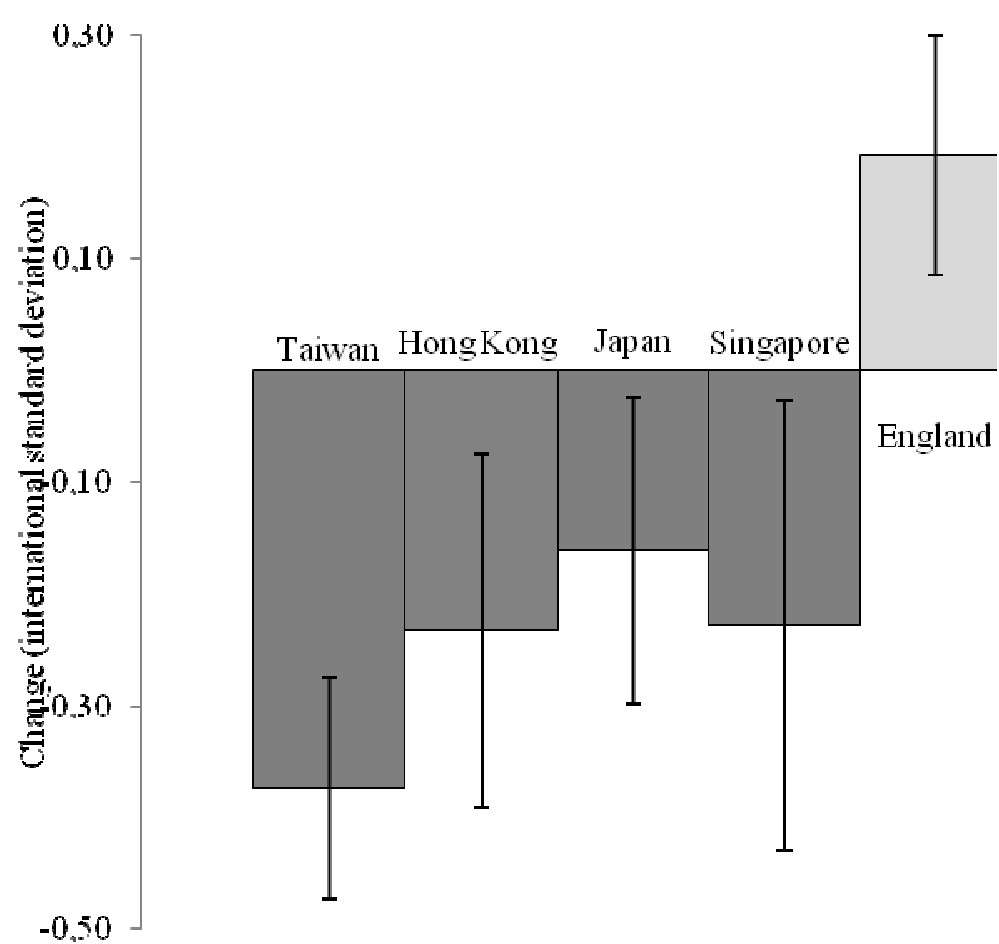

Notes: 1 The left hand panel refers to the change in the $10^{\text {th }}$ percentile of math achievement between age $9 / 10$ (TIMSS $20034^{\text {th }}$ grade) and age $13 / 14$ (TIMSS $20078^{\text {th }}$ grade). The right hand panel provides analogous figures for the change between age 9/10 (TIMSS 2003 $4^{\text {th }}$ grade) and age 15/16 (PISA 2009) .

2 All figures presented in terms of international z-scores.

3 The thin black line running through the centre of each bar is the estimated $90 \%$ confidence interval. All standard errors take into account the clustering of children within schools. See Appendix 1 for further details on methodology. 
Figure 4. Change in the $90^{\text {th }}$ percentile of the math test distribution between the end of primary school and secondary school

(b) Age $9 / 10$ to $13 / 14$

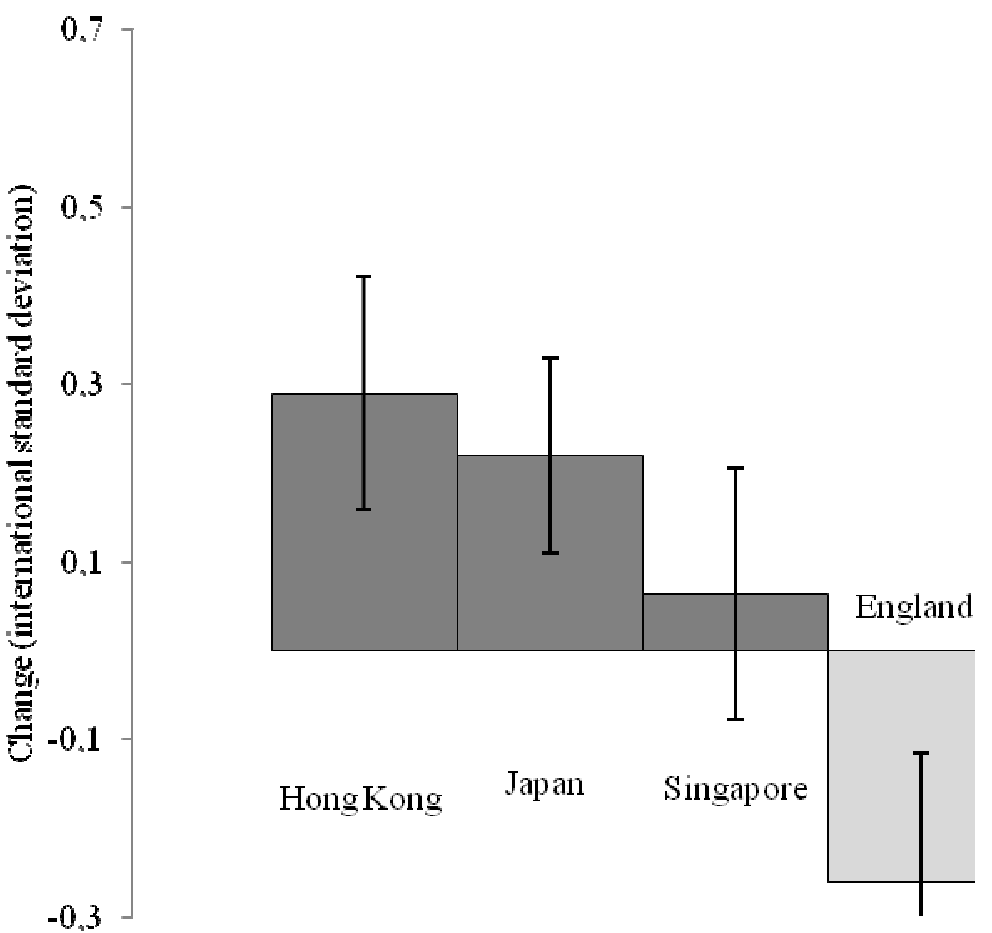

(b) Age 9/10 to $15 / 16$

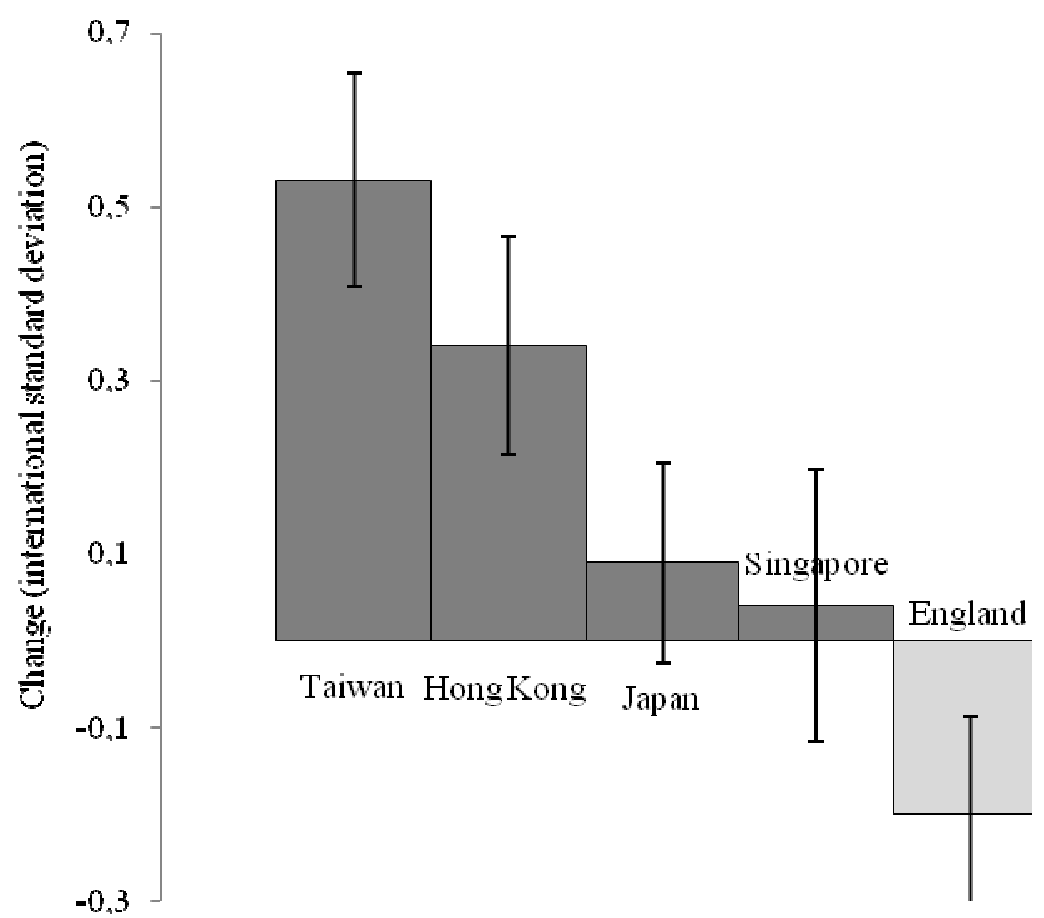

Notes: 1 The left hand panel refers to the change in the $90^{\text {th }}$ percentile of math achievement between age $9 / 10$ (TIMSS $20034^{\text {th }}$ grade) and age $13 / 14$ (TIMSS $20078^{\text {th }}$ grade). The right hand panel provides analogous figures for the change between age 9/10 (TIMSS 2003 $4^{\text {th }}$ grade) and age 15/16 (PISA 2009).

2 All figures presented in terms of international z-scores. The thin black line running through the centre of each bar is the estimated $90 \%$ confidence interval. All standard errors take into account the clustering of children within schools. See Appendix 1 for further details on methodology.

3 Results for Taiwan have been excluded from the left hand panel for clarity of presentation. The $90^{\text {th }}$ percentile is estimated to increase by 0.9 of a standard deviation between age 10 and age 14 in this country (see Table 4 panel b for further details). 
Figure 5. Socio-economic inequality in math test scores at ages 9/10, 13/14 and 15/16

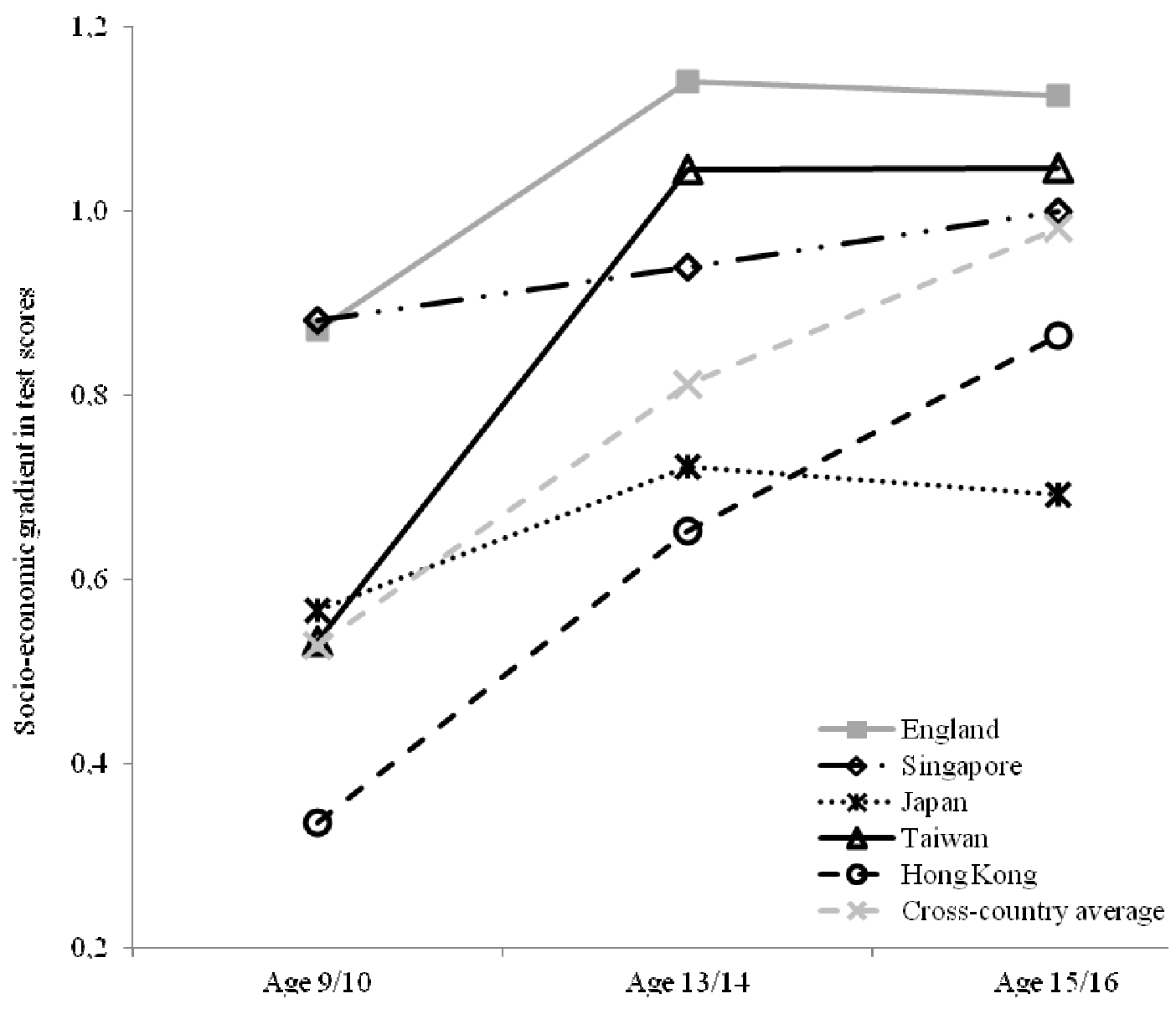

Notes:

1 Estimates refer to differences between children from households with few books $(0-25)$ to those with many books (more than 200 books

2 Age 9/10 refers to TIMSS $20034^{\text {th }}$ grade data, age 13/14 refers to TIMSS $20078^{\text {th }}$ grade data and age $15 / 16$ refers to PISA 2009.

3 All figures presented in terms of international z-scores. 


\section{Appendix 1. Estimates at the $10^{\text {th }}$ and $90^{\text {th }}$ percentile - estimates and standard errors}

\section{(i) Estimates of $10^{\text {th }}$ and $90^{\text {th }}$ percentile of the test distribution}

In Table 4 we present estimates of the $10^{\text {th }}$ and $90^{\text {th }}$ percentile of the test scores distribution at three ages (10, 14 and 16) along with the associated standard errors. These can be produced in STATA by simply running a quantile regression at the given percentile (e.g. P90) with no covariates included. An example of the STATA code used for England at age 10 (TIMSS $20034^{\text {th }}$ grade data) is given below:

$$
\text { qreg Z_Math_Score if Country }==826, q(0.90)
$$

Where 'Z_Math_Score' = The internationally standardised math z-score

The above provides an accurate estimate of the $90^{\text {th }}$ percentile of the test distribution for England. However, standard errors are likely to be underestimated as the clustering of children within schools has not been taken into account. We therefore bootstrap by cluster (schools) all of the estimates produced for the $10^{\text {th }}$ and $90^{\text {th }}$ percentile (using 50 bootstrap replications). An example of the coding used can be found below:

program $q 90$

qreg Z_Math_Score if Country==826, $q(0.90)$

end

bs, cluster(School_ID): $q 90$

\section{(ii) Estimates of change for the $10^{\text {th }}$ and $90^{\text {th }}$ percentile of the test distribution}

In Figure 3 and Figure 4 we present estimates of how the $10^{\text {th }}$ and $90^{\text {th }}$ percentile change as children age (either between ages 10 and 14 or between ages 10 and 16). One way to calculate these changes is to simply subtract the relevant values given in Table 4. For instance, the change in the $90^{\text {th }}$ percentile for England between ages 10 and 14 is given by the calculation $(1.15-1.41=-0.26)$.

An alternative is to the pool the TIMSS $20034^{\text {th }}$ grade (age 10) and TIMSS $20078^{\text {th }}$ grade (age14) data into a single file (post standardisation) and to estimate a quantile regression model with an 'age' dummy variable as a covariate. An example of the STATA code used for England is as follows: 
Where the age dummy takes a value of 1 to indicate TIMSS 2007 (age 14) data. The coefficient for the age dummy variable is thus equal to the change in the $90^{\text {th }}$ percentile between ages 10 and 14 (this can be confirmed for England - where we get a value of -0.26 as explained above). However, standard errors are likely to be underestimated as the clustering of children within schools has not been taken into account. We therefore bootstrap by cluster (schools) all of the estimates produced for the $10^{\text {th }}$ and $90^{\text {th }}$ percentile (using 50 bootstrap replications). An example of the coding used can be found below:

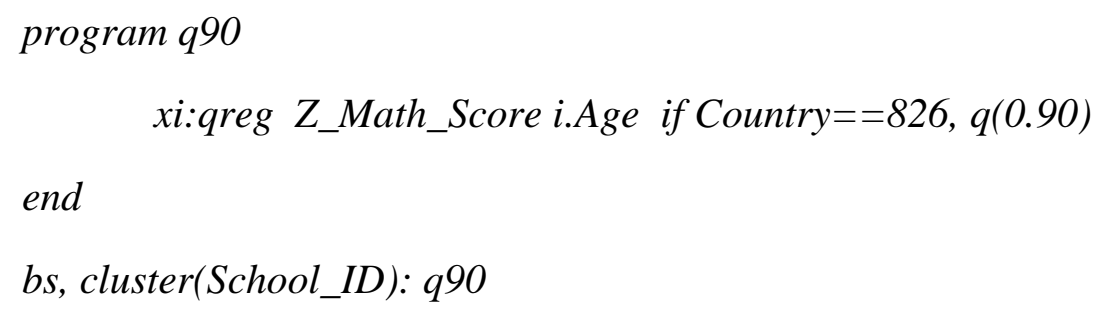

Moreover, note that the above model can be extended to include an 'Age' by 'Country' interaction term:

\section{xi:qreg Z_Math_Score i.Age*i.Country, $q(0.90)$}

If England is set to the baseline country, then the Age*Country interaction will indicate whether the change in the $90^{\text {th }}$ percentile between ages 10 and 14 is statistically significant relative to this country. In other words, is the change in the $90^{\text {th }}$ percentile significantly greater in England than other countries? 
Appendix 2. Response rates across countries and surveys

\begin{tabular}{lcccccc}
\hline & \multicolumn{2}{c}{$\begin{array}{c}\text { 4th grade TIMSS } \\
\text { (2003) }\end{array}$} & \multicolumn{2}{c}{$\begin{array}{c}\text { 8th grade TIMSS } \\
\mathbf{( 2 0 0 7 )}\end{array}$} & \multicolumn{2}{c}{ PISA (2009) } \\
& School & Pupil & School & Pupil & School & Pupil \\
\hline Singapore & 100 & 98 & 100 & 96 & 98 & 91 \\
Japan & 100 & 97 & 97 & 97 & 95 & 95 \\
Taiwan & 100 & 99 & 100 & 100 & 100 & 95 \\
Italy & 100 & 97 & 100 & 97 & 99 & 92 \\
Russia & 100 & 97 & 100 & 98 & 100 & 97 \\
Slovenia & 99 & 92 & 99 & 95 & 98 & 91 \\
Lithuania & 96 & 92 & 99 & 94 & 100 & 93 \\
Norway & 93 & 95 & 93 & 95 & 97 & 90 \\
Australia & 90 & 94 & 100 & 95 & 99 & 86 \\
Hong Kong & 88 & 95 & 79 & 96 & 97 & 93 \\
Scotland & 83 & 92 & 86 & 90 & 89 & 84 \\
England & 82 & 93 & 86 & 93 & 87 & 87 \\
United States & 82 & 96 & 83 & 95 & 78 & 87 \\
\hline Nite:
\end{tabular}

Notes:

1 School response rates refer to after replacement schools have been included.

2 See pages 355 and 357 of http://timss.bc.edu/PDF/t03_download/T03_M_AppA.pdf for TIMSS 2003. See http://timss.bc.edu/timss2007/PDF/T07_M_IR_AppendixA.pdf pages 389 and 391 for TIMSS 2007. For PISA 2009 see http://www.oecd.org/pisa/pisaproducts/pisa2009/50036771.pdf pages 165 to 168 . 
Appendix 3. The cross-country correlation between average PISA 2009 and TIMSS 2011 (8th grade) test scores

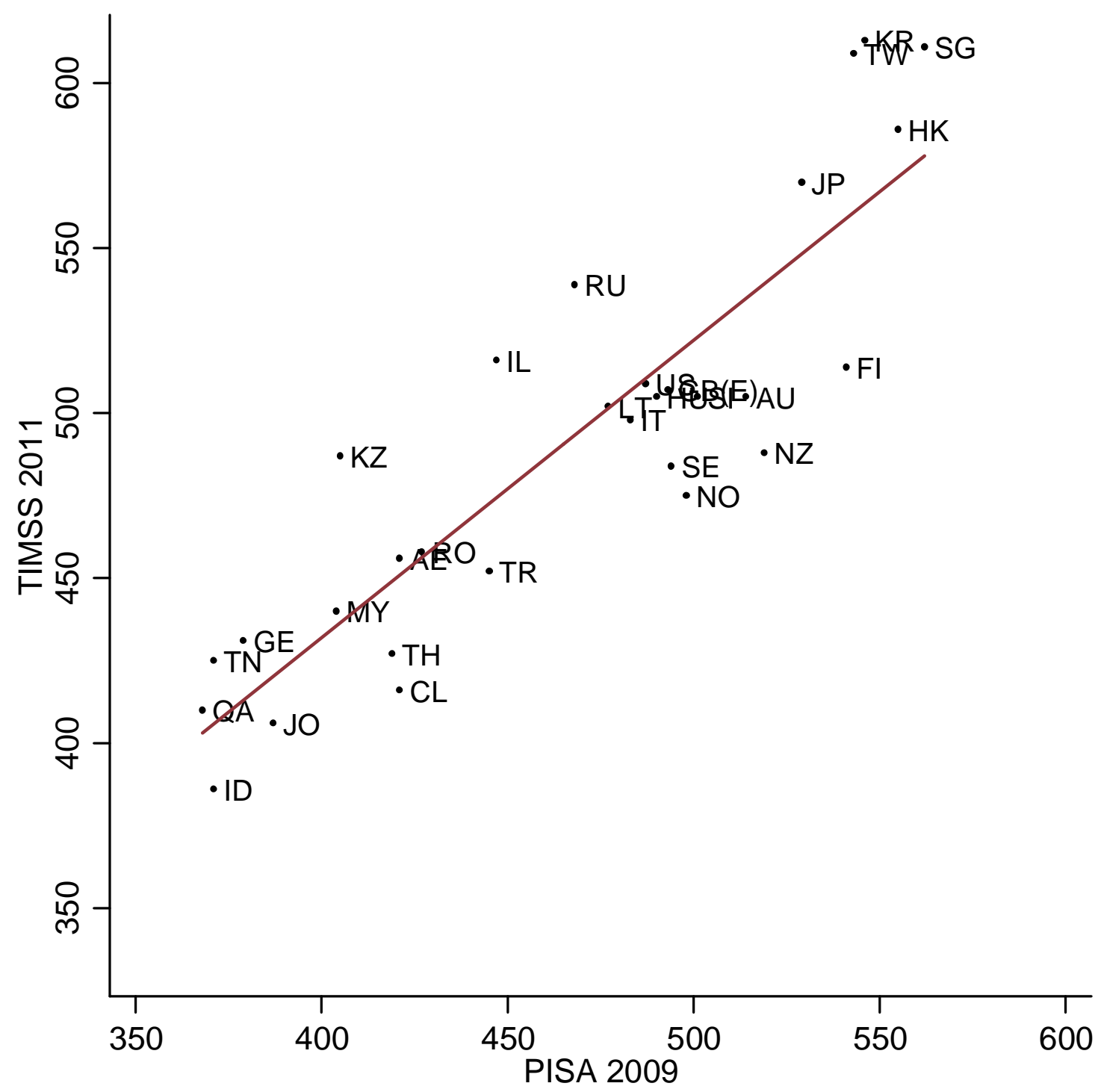

Notes:

1 Data refers to country average (mean) test scores in the PISA 2009 and TIMSS 2011 assessments. These are presented in terms of the PISA / TIMSS test metric - meaning figures are not directly comparable (i.e. a score of 500 on PISA does not mean the same thing as a score of 500 on TIMSS).

2 Pearson correlation coefficient $=0.88$, spearman's rank $=0.86$

3 Official two letter country codes used (www.iso.org/iso/country_names_and_code_elements). GB(E) refers to England. 
2011/1, Oppedisano, V; Turati, G.: "What are the causes of educational inequalities and of their evolution over time in Europe? Evidence from PISA"

2011/2, Dahlberg, M; Edmark, K; Lundqvist, H.: "Ethnic diversity and preferences for redistribution "

2011/3, Canova, L.; Vaglio, A.: "Why do educated mothers matter? A model of parental help"

2011/4, Delgado, F.J.; Lago-Peñas, S.; Mayor, M.: “On the determinants of local tax rates: new evidence from Spain”

2011/5, Piolatto, A.; Schuett, F.: “A model of music piracy with popularity-dependent copying costs”

2011/6, Duch, N.; García-Estévez, J.; Parellada, M.: "Universities and regional economic growth in Spanish regions"

2011/7, Duch, N.; García-Estévez, J.: “Do universities affect firms’ location decisions? Evidence from Spain”

2011/8, Dahlberg, M.; Mörk, E.: "Is there an election cycle in public employment? Separating time effects from election year effects"

2011/9, Costas-Pérez, E.; Solé-Ollé, A.; Sorribas-Navarro, P.: “Corruption scandals, press reporting, and accountability. Evidence from Spanish mayors"

2011/10, Choi, A.; Calero, J.; Escardíbul, J.O.: "Hell to touch the sky? private tutoring and academic achievement in Korea"

2011/11, Mira Godinho, M.; Cartaxo, R.: "University patenting, licensing and technology transfer: how organizational context and available resources determine performance"

2011/12, Duch-Brown, N.; García-Quevedo, J.; Montolio, D.: “The link between public support and private R\&D effort: What is the optimal subsidy?"

2011/13, Breuillé, M.L.; Duran-Vigneron, P.; Samson, A.L.: “To assemble to resemble? A study of tax disparities among French municipalities”

2011/14, McCann, P.; Ortega-Argilés, R.: "Smart specialisation, regional growth and applications to EU cohesion policy"

2011/15, Montolio, D.; Trillas, F.: "Regulatory federalism and industrial policy in broadband telecommunications" 2011/16, Pelegrín, A.; Bolancé, C.: "Offshoring and company characteristics: some evidence from the analysis of Spanish firm data”

2011/17, Lin, C.: "Give me your wired and your highly skilled: measuring the impact of immigration policy on employers and shareholders”

2011/18, Bianchini, L.; Revelli, F.: “Green polities: urban environmental performance and government popularity”

2011/19, López Real, J.: "Family reunification or point-based immigration system? The case of the U.S. and Mexico"

2011/20, Bogliacino, F.; Piva, M.; Vivarelli, M.: "The impact of R\&D on employment in Europe: a firm-level analysis"

2011/21, Tonello, M.: “Mechanisms of peer interactions between native and non-native students: rejection or integration?”

2011/22, García-Quevedo, J.; Mas-Verdú, F.; Montolio, D.: “What type of innovative firms acquire knowledge intensive services and from which suppliers?”

2011/23, Banal-Estañol, A.; Macho-Stadler, I.; Pérez-Castrillo, D.: “Research output from university-industry collaborative projects"

2011/24, Ligthart, J.E.; Van Oudheusden, P.: “In government we trust: the role of fiscal decentralization”

2011/25, Mongrain, S.; Wilson, J.D.: “Tax competition with heterogeneous capital mobility”

2011/26, Caruso, R.; Costa, J.; Ricciuti, R.: “The probability of military rule in Africa, 1970-2007"

2011/27, Solé-Ollé, A.; Viladecans-Marsal, E.: “Local spending and the housing boom”

2011/28, Simón, H.; Ramos, R.; Sanromá, E.: “Occupational mobility of immigrants in a low skilled economy. The Spanish case"

2011/29, Piolatto, A.; Trotin, G.: “Optimal tax enforcement under prospect theory”

2011/30, Montolio, D; Piolatto, A.: "Financing public education when altruistic agents have retirement concerns"

2011/31, García-Quevedo, J.; Pellegrino, G.; Vivarelli, M.: “The determinants of YICs’ R\&D activity”

2011/32, Goodspeed, T.J.: "Corruption, accountability, and decentralization: theory and evidence from Mexico"

2011/33, Pedraja, F.; Cordero, J.M.: "Analysis of alternative proposals to reform the Spanish intergovernmental transfer system for municipalities"

2011/34, Jofre-Monseny, J.; Sorribas-Navarro, P.; Vázquez-Grenno, J.: “Welfare spending and ethnic heterogeneity: evidence from a massive immigration wave"

2011/35, Lyytikäinen, T.: “Tax competition among local governments: evidence from a property tax reform in Finland"

2011/36, Brülhart, M.; Schmidheiny, K.: “Estimating the Rivalness of State-Level Inward FDI” 
2011/37, García-Pérez, J.I.; Hidalgo-Hidalgo, M.; Robles-Zurita, J.A.: “Does grade retention affect achievement? Some evidence from Pisa”

2011/38, Boffa, f.; Panzar. J.: "Bottleneck co-ownership as a regulatory alternative”

2011/39, González-Val, R.; Olmo, J.: "Growth in a cross-section of cities: location, increasing returns or random growth?”

2011/40, Anesi, V.; De Donder, P.: "Voting under the threat of secession: accommodation vs. repression”

2011/41, Di Pietro, G.; Mora, T.: "The effect of the l'Aquila earthquake on labour market outcomes"

2011/42, Brueckner, J.K.; Neumark, D.: "Beaches, sunshine, and public-sector pay: theory and evidence on amenities and rent extraction by government workers"

2011/43, Cortés, D.: "Decentralization of government and contracting with the private sector"

2011/44, Turati, G.; Montolio, D.; Piacenza, M.: "Fiscal decentralisation, private school funding, and students' achievements. A tale from two Roman catholic countries"

2012/1, Montolio, D.; Trujillo, E.: "What drives investment in telecommunications? The role of regulation, firms' internationalization and market knowledge"

2012/2, Giesen, K.; Suedekum, J.: "The size distribution across all "cities”: a unifying approach"

2012/3, Foremny, D.; Riedel, N.: "Business taxes and the electoral cycle"

2012/4, García-Estévez, J.; Duch-Brown, N.: "Student graduation: to what extent does university expenditure matter?"

2012/5, Durán-Cabré, J.M.; Esteller-Moré, A.; Salvadori, L.: "Empirical evidence on horizontal competition in tax enforcement"

2012/6, Pickering, A.C.; Rockey, J.: "Ideology and the growth of US state government"

2012/7, Vergolini, L.; Zanini, N.: "How does aid matter? The effect of financial aid on university enrolment decisions"

2012/8, Backus, P.: "Gibrat's law and legacy for non-profit organisations: a non-parametric analysis"

2012/9, Jofre-Monseny, J.; Marín-López, R.; Viladecans-Marsal, E.: "What underlies localization and urbanization economies? Evidence from the location of new firms"

2012/10, Mantovani, A.; Vandekerckhove, J.: "The strategic interplay between bundling and merging in complementary markets"

2012/11, Garcia-López, M.A.: "Urban spatial structure, suburbanization and transportation in Barcelona"

2012/12, Revelli, F.: "Business taxation and economic performance in hierarchical government structures"

2012/13, Arqué-Castells, P.; Mohnen, P.: "Sunk costs, extensive R\&D subsidies and permanent inducement effects"

2012/14, Boffa, F.; Piolatto, A.; Ponzetto, G.: "Centralization and accountability: theory and evidence from the Clean Air Act"

2012/15, Cheshire, P.C.; Hilber, C.A.L.; Kaplanis, I.: "Land use regulation and productivity - land matters: evidence from a UK supermarket chain"

2012/16, Choi, A.; Calero, J.: "The contribution of the disabled to the attainment of the Europe 2020 strategy headline targets"

2012/17, Silva, J.I.; Vázquez-Grenno, J.: "The ins and outs of unemployment in a two-tier labor market"

2012/18, González-Val, R.; Lanaspa, L.; Sanz, F.: "New evidence on Gibrat’s law for cities"

2012/19, Vázquez-Grenno, J.: "Job search methods in times of crisis: native and immigrant strategies in Spain"

2012/20, Lessmann, C.: "Regional inequality and decentralization - an empirical analysis"

2012/21, Nuevo-Chiquero, A.: "Trends in shotgun marriages: the pill, the will or the cost?"

2012/22, Piil Damm, A.: "Neighborhood quality and labor market outcomes: evidence from quasi-random neighborhood assignment of immigrants"

2012/23, Ploeckl, F.: "Space, settlements, towns: the influence of geography and market access on settlement distribution and urbanization"

2012/24, Algan, Y.; Hémet, C.; Laitin, D.: "Diversity and local public goods: a natural experiment with exogenous residential allocation"

2012/25, Martinez, D.; Sjögren, T.: "Vertical externalities with lump-sum taxes: how much difference does unemployment make?"

2012/26, Cubel, M.; Sanchez-Pages, S.: "The effect of within-group inequality in a conflict against a unitary threat" 2012/27, Andini, M.; De Blasio, G.; Duranton, G.; Strange, W.C.: "Marshallian labor market pooling: evidence from Italy"

2012/28, Solé-Ollé, A.; Viladecans-Marsal, E.: "Do political parties matter for local land use policies?" 
2012/29, Buonanno, P.; Durante, R.; Prarolo, G.; Vanin, P.: "Poor institutions, rich mines: resource curse and the origins of the Sicilian mafia"

2012/30, Anghel, B.; Cabrales, A.; Carro, J.M.: "Evaluating a bilingual education program in Spain: the impact beyond foreign language learning"

2012/31, Curto-Grau, M.; Solé-Ollé, A.; Sorribas-Navarro, P.: "Partisan targeting of inter-governmental transfers \& state interference in local elections: evidence from Spain"

2012/32, Kappeler, A.; Solé-Ollé, A.; Stephan, A.; Välilä, T.: "Does fiscal decentralization foster regional investment in productive infrastructure?"

2012/33, Rizzo, L.; Zanardi, A.: "Single vs double ballot and party coalitions: the impact on fiscal policy. Evidence from Italy"

2012/34, Ramachandran, R.: "Language use in education and primary schooling attainment: evidence from a natural experiment in Ethiopia"

2012/35, Rothstein, J.: "Teacher quality policy when supply matters"

2012/36, Ahlfeldt, G.M.: "The hidden dimensions of urbanity"

2012/37, Mora, T.; Gil, J.; Sicras-Mainar, A.: "The influence of BMI, obesity and overweight on medical costs: a panel data approach"

2012/38, Pelegrín, A.; García-Quevedo, J.: "Which firms are involved in foreign vertical integration?"

2012/39, Agasisti, T.; Longobardi, S.: "Inequality in education: can Italian disadvantaged students close the gap? A focus on resilience in the Italian school system"

2013/1, Sánchez-Vidal, M.; González-Val, R.; Viladecans-Marsal, E.: "Sequential city growth in the US: does age matter?"

2013/2, Hortas Rico, M.: "Sprawl, blight and the role of urban containment policies. Evidence from US cities"

2013/3, Lampón, J.F.; Cabanelas-Lorenzo, P-; Lago-Peñas, S.: "Why firms relocate their production overseas? The answer lies inside: corporate, logistic and technological determinants"

2013/4, Montolio, D.; Planells, S.: "Does tourism boost criminal activity? Evidence from a top touristic country"

2013/5, Garcia-López, M.A.; Holl, A.; Viladecans-Marsal, E.: "Suburbanization and highways: when the Romans, the Bourbons and the first cars still shape Spanish cities"

2013/6, Bosch, N.; Espasa, M.; Montolio, D.: "Should large Spanish municipalities be financially compensated? Costs and benefits of being a capital/central municipality"

2013/7, Escardíbul, J.O.; Mora, T.: "Teacher gender and student performance in mathematics. Evidence from Catalonia"

2013/8, Arqué-Castells, P.; Viladecans-Marsal, E.: "Banking towards development: evidence from the Spanish banking expansion plan"

2013/9, Asensio, J.; Gómez-Lobo, A.; Matas, A.: "How effective are policies to reduce gasoline consumption? Evaluating a quasi-natural experiment in Spain"

2013/10, Jofre-Monseny, J.: "The effects of unemployment benefits on migration in lagging regions"

2013/11, Segarra, A.; García-Quevedo, J.; Teruel, M.: "Financial constraints and the failure of innovation projects" 
